\title{
Race and racism in international relations: retrieving a scholarly inheritance
}

\author{
Robbie Shilliam ${ }^{1}$
}

Accepted: 6 November 2020 / Published online: 28 November 2020

(c) Springer Nature Limited 2020

\begin{abstract}
This conversation draws out the personal, social, political and intellectual contexts in which a generation of IR scholars came to re-engage the field with the study of race and racism.
\end{abstract}

Keywords Disciplinary history $\cdot$ Colonialism $\cdot$ Empire $\cdot$ Race $\cdot$ Racism

\section{Editor's introduction}

The summer of 2020 was rocked by Black Lives Matter protests and uprisings, and not only in the US. According to Hakim Adi, an influential historian of Pan-Africanism, the scale and longevity of this, the latest iteration of the movement for black lives, was historically unprecedented (Mohdin and Swann 2020). Academia has not been insulated from the BLM phenomenon; neither has the field of International Relations. For instance, the British International Studies Association (BISA 2020) provided a thoughtful statement in June, acknowledging that IR has "often [been] deeply implicated in the kind of race work which upholds racist structures and relations". The International Studies Association (ISA 2020) released a rather lukewarm acknowledgment of generic "racism" rather than black lives, and spoke in the language of diversity and inclusion rather than structural injustices. Still, respond it did. A number of other organizations related to the IR world by policy, research or teaching also took stock-take, publicly or privately.

IR magazines and journals similarly felt the need to respond. Foreign Policy magazine solicited a number of interventions on race and racism in IR, starting with a

In conversation with Anna M. Agathangelou, Shampa Biswas, Neta Crawford, Roxanne Doty, Locksley Edmondson, Siba N. Grovogui, Errol Henderson, Audie Klotz, Sankaran Krishna, Sheila Nair, Mustapha Kamal Pasha, Randolph B. Persaud, Shirin M. Rai, Robert Vitalis, and Rob Walker.

Robbie Shilliam

r.shilliam@jhu.edu

1 Baltimore, MD, USA 
wonderful state-of-play article by Zvobgo and Loken (2020), comprehensively covering research and teaching. The magazine followed this up with various interventions by other scholars of race and racism in the field (Shilliam 2020; Bhambra et al. 2020). Subsequently, Foreign Affairs published a think-piece by historian Keisha Blain (2020) on the international dimensions of the US Black freedom struggle.

It is easy to forget now, but just prior to the eruption of BLM protests and uprisings the field had witnessed an academic controversy over race, when Wæver and Buzan (2020) responded emotively and at length to an article published by Howell and Richter-Montpetit (2020) asking if securitization theory was racist and answering in the affirmative. However, this academic controversy did not erupt out of thin air, but arrived as part of a deep and long-term swell in the critical study of race in IR. In fact, the 2010s were marked by an intensification of monographs, conferences, panels and workshops focusing on race and racism which, at least in part, tracked the rise of BLM as well as other movements such as Rhodes Must Fall, Idle No More etc.

Of course, one might ask how far back does this tradition of critical inquiry go. And the answer, we now know, is all the way to the field's inception at (late 19th century) fin de siècle. Still, between then and the last decade, there exists a fair span of time. Scholars are still alive and active in the field, most of whom undertook graduate school in the 1980s, and who were publishing on race and racism in IR in the 1990s and 2000s. In many ways, this generation of scholars retrieved and relaunched the critique of race and racism in IR that, as a tradition, had largely moved out of IR or otherwise held in abeyance. What are the living histories-personal, familial, intellectual, political—of these senior scholars, and how might they inform the present debate?

The aim of bringing this diverse cohort of scholars together in collective reflection is to interrupt the well-meaning yet ultimately disabling rush to account for race and racism as if it has never been accounted for before in IR. This interruption has all-at-once intellectual and political implications which might be apprehended by way of the idea of inheritance. Power is efficacious when it is institutionalized. Institutionalization requires structures that exceed the energies, reach, lifetimes and memories of individuals. Power is inherited and disposed of inter-generationally. Subjection requires the cutting of lines of inheritance and the consistent resetting of energies, ideas, memories and strategies to year zero.

The retrieval of inheritances as living multifaceted resources-or counterarchives - allows us to deepen and widen our conceptual, theoretical and empirical inquiries into race and racism in IR. If all collective projects are able to proffer an inheritance, then instead of a singular canon, students and scholars might benefit from a democratized and expansive constellation of knowledge. A critical appraisal of the present could therefore become more incisive, edifying, efficacious. True, the stakes at play in academia are immediately less than those at play with organizers on the front lines in the struggle over global justice; but the academic stakes do not necessarily exist separately from this wider world.

There are many incredible and influential scholars who during the 1990s and 2000s made key contributions to the study of imperialism and/or the postcolonial condition in IR. Such contributions have not always engaged directly with the issue 
of race. This is not an indictment; it is merely to say that from such scholars I invited to the table those who had undertaken more directive engagements with race and racism in that time period-whether or not they consider themselves to be "race scholars". Furthermore, I not only invited scholars who had published to this effect, but also those who made important contributions in infrastructural ways. A notable collective project, in this respect, was the special issue entitled "Apertura: Race in International Relations" (Persaud and Walker 2001), published in Alternatives in 2001 featuring many of the contributors to this conversation. Additionally, a number of contributors also published individual pieces of work on race before this special issue (Doty 1993b; Krishna 1993; Errol Anthony Henderson 1995; Grovogui 1996; Persaud 1997; Vitalis 2000).

I was not able to canvas all scholars who made contributions according to these broad criteria. And, to be honest, I am not even sure how tenable-or usefulthose criteria ultimately are, especially the artificial distinction between discourses of race, postcoloniality and imperialism. Nonetheless, fifteen contributors yielded 22,000 words, and that is with at least a third of the conversation cut out. It was not my intention to launch a book but to facilitate a solid, timely and initial response to the summer of 2020. Without doubt, more research needs to be done to tell the whole story and build up the counter-archive. And towards this aim we should always keep in mind the intersectional politics of citations. For instance (and I thank Errol Henderson for this awareness) a number of Black women political scientists such as Annette Palmer (see 1983), Mae King (see 1985) and Karin Stanford (see 1997) wrote treatises on race and/or postcolonialism and foreign/military policy in the 1980s and 1990s yet do not seem to have been integrated into the field of IR specifically, even by critical scholars.

Ultimately, the list of contributors comprised: Anna M. Agathangelou, Shampa Biswas, Neta Crawford, Roxanne Doty, Locksely Edmondson, Siba N. Grovogui, Errol Henderson, Audie Klotz, Sankaran Krishna, Sheila Nair, Mustapha Kamal Pasha, Randolph B. Persaud, Shirin M. Rai, Robert Vitalis, and Rob Walker. Of this list, two scholars-Edmondson and Walker-might be said to belong to an earlier intellectual generation to the rest, and who in different ways demonstrate a living connection between intellectual/political debates over race, anti-colonialism and international relations in the 1960s and 1970s and those that re-started in the 1990s. Our conversation proceeded via two zoom conferences and was followed up by separate zoom and email correspondences which also brought in three more people (Crawford, Edmondson and Henderson) who were not present for the original conversations. From these conversations I drew out a set of themes and rearranged the transcribed texts to fit those themes. (My thanks to Shahab ud Din Ahmad, Liz Alexander, Ruoyu Li and Aila Traski for their transcribing labors.) I then gave the resultant text back to the interlocutors for them to expand, delete and amend as they saw fit.

The main purpose in undertaking this editorial process was to afford early career scholars studying race and racism in IR (and anyone interested in the issue) a finer orientation towards the living histories of this study, and to draw out the ways in which the braided legacies of racism, colonialism and empire are intimately integral to the field of IR. To this end, I thematized the conversation as follows: points of 
departure, movements, graduate school, formative experiences of the field, intersectionality, and the contemporary field.

In sum, these conversations demonstrate that the eruption of race and racism into IR is not a new phenomenon. It is a regular recurrence. That is the beauty and the dread of the thing. We have an inheritance to critically and creatively work with.

(In what follows, comments in [] parentheses, as well as all citations, were added by the editor).

\section{Points of departure}

\section{Locksley Edmondson}

I was born in Jamaica (then a British colony) where I completed my primary and secondary school education before leaving in 1957 to pursue an undergraduate degree in England, at the University of Birmingham.

My father, a primary school teacher, rose through the ranks to become a Jamaica Principal Education Officer. My mother too rose through the ranks to become a Primary School Principal. I grew up in colonial Jamaica with books around me at home. My father constantly sought to nurture a sense of Jamaican nationalism by often re-interpreting the names of British-published book entries for a better understanding by Jamaican school children. For example, I still remember him reading Shakespeare's "The Tempest" and teasing out the colonialist/colonialized dynamics. He constantly sought to "Jamaican-ize" the primary school curriculum.

Shortly after my high school graduation, I left Jamaica in 1957 to pursue undergraduate studies in England at the University of Birmingham where in 1960, I completed a Bachelor of Social Sciences Honors degree, majoring in Economics, Politics and Sociology. The most unforgettable experiences I encountered in Britain were race-related. For example, I was stunned when on turning up for my first summer job as a gardener in a large English factory, I was greeted by the head gardener as follows: "I know that they call people like you 'Negro' but I prefer to call you 'Darkie'." This was a period when British newspaper ads about home/apartment rentals would routinely include "No Blacks need apply" or even "No Jamaicans need apply."

But the most rewarding and beneficial experiences of my British sojourn derived from my living among and learning about the colonial experiences of several African, Asian and other Caribbean students with whom I shared living quarters during these years of decolonization.

A significant intellectual turning point occurred in my final year undergraduate experience at Birmingham. In a class on "Political Sociology" our young Professor 1 day distributed a list of research/essay topics, asking each student to choose any one topic for their final research paper. I instantly chose, "The American Negro". From then on, I was "hooked" on the study of race relations. This was the starting point of my research on race relations which eventually culminated in my far-future PHD thesis topic: "Race, Politics and the International System: Aspects of Research and Behaviour" (Edmondson 1973). 


\section{Rob Walker}

I have to say that I cannot claim any special expertise about race from an academic point of view. Moreover, I'm a white boy who grew up in the English provincial town of Reading, just west of London. Still, even though I would say that I am personally marked much more by the politics of class, being an early beneficiary of the welfare state, I have had quite a lot of contact with colonial and racist practices. For various family reasons, I was especially aware of the cultural diversity at play even in such a bland town as Reading, and of the internal colonialism of the UK itself. Even while still at school I became intensely aware of the cultures and politics of music and came into contact with musicians from the US, the Caribbean and South Africa who were dramatically reshaping the cultural life of Little England. It was impossible to ignore racism in that context, although I was simultaneously following debates on the left about relations between race, class and gender, and worrying about the nuclear bomb designers working just down the road.

I then escaped to the very different world of Canada in 1968. From there I travelled a lot through much of the USA, most of which I experienced as a volatile and threatening place. New York and Detroit especially reshaped my understanding of race. I was probably more shocked by the visceral character of white racism that I saw in so many places as well as by the still pervasive presence of both the Civil War and puritanisms of many kinds.

So, existentially, I have some sort of sense of how race plays out in the UK and the US, as well as of some of the complex contextualization necessary to understand both. I am also aware of the history of racism in Canada, but given the specific places in which I have lived, experiences of indigeneity and many other forms of colonialism have been more pressing for me, especially when linked to threats to local and planetary ecologies.

All this is to say that I engage with race as part of a broader intellectual and political agenda, one that is ultimately grounded in questions about what it means to speak about humanity in general and in particular. For me, this is what "international relations" is about, and explains much of how the discipline systematically excludes most "social" understandings of what it means to be human. Consequently, I have seen no alternative but to try to understand what it means to think about "relations," not only between race, class and gender but about the multitude of human relations that are so powerfully but inadequately captured in the notion of an international as well as by the discipline that claims some privileged expertise about it.

Much of how I try to do this I learnt from the music of my youth: from a radical black avant-garde, on the one hand, and from an also radical European avant-garde on the other hand. I also learnt early on that every experience is easily capturedcommodified, reified, abstracted-in ways that reproduce prevailing forms of power. As with music, so in politics, as Plato once said. This is why I have tried very hard to make some spaces in which many excluded experiences might be expressed, as well as to understand the mutating ways in which they are suppressed. Many people-many good friends - have tried to put race onto the disciplinary agenda, but that agenda is heavily overdetermined by other accounts of what it means to be both 
human and to be politically qualified. Race is a crucial aspect of a broader pattern in this respect.

\section{Randolph Persaud}

My entry into international relations where race is concerned probably started very early, because British Guiana, when and where I was born, was still a colony. We had the Queen in our classroom exercise books, and once in a while the Governor General would go by and we would stand there and they would raise the flag. And that was a very confusing thing because I grew up on a sugarcane plantation which bore no resemblance to the Queen. Contradiction is lived experience.

Here's how the plantation was set up. You had the sugarcane field starting less than a mile from the Atlantic Ocean, stretching all the way as far as you could see into the back-dam, going south. Immediately before the cane-fields there was the factory. There was a senior staff compound where the management, almost all of them white from Britain lived, fenced-off and guarded. And you had the junior staff compound where people who worked at the administrative office did not live but socialized. The junior staff clubs were for staff and children and whatever family or friends you could 'smuggle in' on movie nights. Then you had the sugarcane workers. Almost everybody worked in the fields if they were not working in the city with the government.

And so that's how the space was actually organized, and there was hardly any contact between groups. Before I left Guyana, I think I only spoke with two white people - and I left at 18 years old. And we did not have televisions. The only way you might encounter race would be through movies, but they were heavily edited. So I actually came to race in IR through anti-imperialism. We had political parties that were Marxist [the People's National Congress and the People's Progressive Party]. The Pentagon, the CIA, and American intervention regularly got trashed in their speeches. When political parties rallied in villages, the entire family would go- - sometimes a few hundred people, children and all. The meetings went on for two or three hours late into the night. And it would basically be non-stop criticisms of imperialism. Once in a while, they would throw in colonialism, but we hardly ever heard any criticisms of colonialism, or of the Queen, or of British intelligence or anybody else. By the time I read Fanon in my second year at York University, I already had a sense of space and what today we call the coloniality of power.

\section{Roxanne Doty}

Well, my way back beginnings are probably a bit more U.S. parochial. When I was 10 years old, which was a real formative period as a child, I lived in the South-in Nashville, Tennessee with my grandmother. This was in the 1960s. My first awareness of race came when the Birmingham Church was blown up. [In 1963, the Ku Klux Klan bombed the 16th Street Baptist Church in Birmingham, killing four girls and injuring dozens of others]. 
There was a lot of conflict in my grandmother's neighborhood. I discovered that my relatives there were racist, and my grandmother, who I really loved, was also a racist. I had a little African American friend. We had to meet at the edges of our yard. It's just a minor childhood experience, yet whenever I think back, it was one of the most formative childhood experiences. Anyway, that thought of "wow, what is going on here?" just stayed with me. This was a personal kind of awareness.

\section{Audie Klotz}

I grew up in Chicago. And if you know anything about the U.S., you'll know that there is the north and south side of the city. To my mind, you cannot grow up in Chicago without at least with some superficial awareness of race and racism. That said, there are a lot more complexities growing up in Chicago and I understood layers and layers of that through other subsequent experiences as an adult when I left the city and then returned.

\section{Errol Henderson}

I was raised in the Brewster projects in Detroit and my first memories are of the 1967 revolt. I was just 4 years old but I remember tanks and armored personnel carriers coming down our streets. And the lights were out and they polluted our water. Anyway, one of my sisters was in the Black Panther Party, and a brother was in Vietnam. So, I had politics in my house. In the projects, when I was coming up, some of the main options were that you sell dope, work in the [car manufacturing] plant or go to jail-college was rare. I went into the US Army at seventeen and 2 years later, I began college. I used to walk from the projects to Wayne State University. I was angry for a lot of reasons. But Wayne State University had traditions going back to the League of Revolutionary Black Workers [formed in Detroit in 1969] and before. So, I put that anger into organizing-we revived the Association of Black Students. I graduated in 3 years, magna cum laude.

\section{Shirin M. Rai}

I grew up in Delhi. Colonialism as "ever present but never present" might be a good way of putting it. I went to school in the 1970s, and my year was the first to get the most wonderful education in the history of India by good old Indian Marxists such as Bipin Chandra and Sumit Sarkar who were now writing school and college textbooks. Unlike Randolph's upbringing in Guyana, we did a lot of learning on empire, colonialism, independence struggles and India's place in world history. It was also a very hopeful time, politically speaking. My parents were involved in the anti-Vietnam War movement, and they supported pro-Palestinian groups and antiapartheid groups. My father went to Cuba in 1962 and became enchanted with this new way of thinking about socialism, and my mother was a leader of the National Federation of Indian Women. However, the downside of growing up in in a very 
Marxist family was that, of course, class trumps everything. Class trumps gender, class trumps caste.

Our relationship with Empire was one of hate and love. My parents were part of the communist and nationalist student movement against the British, but they also loved all the cultural trappings of western literature and music. I remember Chinese diplomats coming to our house once; they had just seen the Bollywood film called Junoon (1978). One of them said-“I can't understand you guys: why do you [Indians] love the British so much? You just don't hate them! We hate them! We hate our colonial masters! What's wrong with you?!" So that was the first time I remember feeling: "oh my god, there's a new perspective!"

But, as I intimated, I also look back on this time in terms of a total denial of caste politics, which of course, similar to Black Lives Matter nowadays, became really prominent in Indian politics after I had left the country. Although we were upper caste in background (just as we were Hindus culturally) we saw ourselves as non-caste people. So, the kind of slavery issues and the kind of marginalization and oppression issues in the Indian context was simply erased due to the politics of caste. But it was there, obviously it was there, and caste has now become something that we all have to engage with just like race is something we all have to engage with.

\section{Siba N. Grovogui}

My dad was a labor organizer, and he was the head of the third largest labor confederation in the country. He was fourth-grade educated, and taught himself to read with the books of Karl Marx. In Guinea, my country, after Aimé Césaire [a cofounder of the négritude movement and, later, deputy to the French National Assembly for Martinique] had left the French Communist Party (1956), a group of labor organizations created UGTAN (Union Generale des Travailleurs d'Afrique Noire). They added "AN", for Afrique Noir. So the French had UGT (Union Generale des Travailleurs) and the Africans, in Guinea in particular, we had UGTAN, which was very, very radical.

And my father had his own reading about why they created UGTAN, why they decided not to be just communist but to be communist and black. Growing up, my father told me about Toussaint L'ouverture. He explained to me: "you are black, you are Indian, you are everybody, because the world belongs to you"; and he said, "if you go to India and someone were to call you Indian, that should be perfectly normal, because that's them extending their humanity to you". My father was very clear that everybody should call him whatever they are. If you are Indian, call him Indian. But my father also added that if I was going to India and somebody called me Indian they should also call me untouchable. And that has cost me relationships. Because in India I would be what is called untouchable.

My father told me that Makarios III [a clergyman and the first president of Cyprus] was African and Tito [president of Yugoslavia and a leader of the NonAligned Movement] was African. If you don't believe me just google the Syli [the Guinean currency between 1971 and 1985]. It had pictures of all the freedom fighters of Africa on it, and the figure on the largest note, the 500 Syli, was Tito. To us, 
Tito was an African and we called everybody African because their humanity was equal to ours. My father was very clear about that.

My father also told me that they rejected the communist project because communists didn't seem to know that plantations and colonialism existed and that plantation workers were as numerous as factory workers. And so, to say "the workers are going to save the world" would be to misunderstand how the world was made, basically. And that's how my father introduced me to race. It wasn't in an exclusive fashion, but it was to own up to the fact that I am black. As Toussaint Louverture, would say, "nous sommes tous Haïtiennes"-we are all Haitians (Grovogui 2008).

The first time I called Rob Walker "cousin" he was probably baffled, but that's because in my anti-colonial mind the Irish and the Welsh were never white. And I often remember that Cromwell started with them: everything that we experienced then started with them. And that's why the Irish were never actually white. And I want to say all of this because I had a very strange upbringing by a man who was very invested in questions of race and class, who was really not terribly educated: 4th grade, right? And he taught himself how to read about the world.

\section{Anna M. Agathangelou}

I am going to start with a couple of things. For me, and as Siba has just mentioned, race in IR does not begin with the discipline or any of the intellectuals that we are all familiar with. It begins with my own history, family, and positionality in a very small island [Cyprus] in the Mediterranean. I want to recall a few words from my grandfather, who used to say "remember fourteen generations, and involve yourself like a lion in the struggle." So, I just want to begin with that recollection, which is part of what informs my own engagement with race and IR. But also, I want to acknowledge being a substantive witness of racism in my own life, which began before coming to the USA.

One of the things that is central to me has been the stories and struggles around the question of violence (conflicts, war) and imperialism, but with far broader trajectories than just the Western kind. The reason I am saying this is because I was brought up with stories of the material effects of power distribution that ran longer than the British imperialism that Cyprus experienced.

Both of my parents have been involved in communist and socialist struggles (my mother was a communist and my father was a socialist), which probably reveals a lot about who I am. Involved in organizing, they struggled daily to articulate and put forward a vision of the world otherwise, where racial subjugation could not be explained away as an aid to class exploitation. Their vision was never solely about class; it was always at the same time about issues of enslavement, colonization, and imperialism. They remembered a lot of histories and material experiences that started in Cyprus with the first plantation.

The Italian city-states began the first experiments on plantations with sugar. Cyprus was very central, in addition to some small African islands. [In the 15th century, Cyprus was the prime sugar producer in the Mediterranean; in the mid16th century, São Tomé and Príncipe were the prime sugar producers in the African 
continent]. My grandfather used to show us different living sites of sugar production, like Kolossi, Potamia and Kouklia. As some Cypriots expended most of their time and energy to grow their own food and did not want to work in sugar production, slave labor was brought in from the Black Sea area. In Cyprus, water is abundant in the winter but less available in the heat of summer. Yet the cane grows fastest in the summer. Securing a reliable source of water for irrigation and motive power required the construction of costly water transportation and irrigation systems, which also dramatically changed the epidemiology and environment of the island. After the first generation, a net natural decrease in plantation populations would not be expected. The place of Cyprus in global history was not simply as Europe's leading medieval producer of sugar but also as part of the creation of the plantation complex.

These materialities, life conditions and questions pertaining to the island informed and shaped my own intellectual development as well as my own substantive experiencing and witnessing of racism. In a way, these generational issues inform and shape how I think about race because it was part and parcel of my formative conversations. For instance, I was brought up with stories of how the sugar plantation complex shaped the island, and of how people talked about monuments and bridges not as ancient artifacts but as living sites by pointing out that "this is where the plantation was set up," and this is "where your ancestors" made your life possible.

That's one part of the story. Another part of the story that I was brought up with related to copper. Cyprus was central to mining and of course not just the British but the Swedish, the Norwegians all played a huge role in the political economy of mining in Cyprus. For me, these stories point to the fact that the struggles of my family and of Cyprus were connected to the non-aligned movement. You might know of Makarios III.

\section{Siba N. Grovogui}

Makarios? The African.

\section{Anna M. Agathangelou}

Yes, the African! He was our leader and a very central figure in the Non-Aligned Movement. My father would take me to all his political speeches. My mother used to take me to the brick factory where she used to work. Ever since I can remember, I was politicized. Politics was not an afterthought-it was not something that was out there. And of course, the mere factor that you had a leader that was so centrally involved in the anti-colonial struggle really informed and shaped how we thought of the island as well as the colonial, imperial and racial divisions within the island, which were from the beginning all comprised of global raciality. The ordering of people, their politics - socialist, communists, liberals - mapped onto the division of the three worlds in a way, and also the division of different empires. Cyprus was part of the Ottoman Empire, and before that, the Venetians, so that really brings a much longer trajectory into view when we think about race and IR. 
In 1974 Turkey invaded Cyprus and the island became divided. This was a very personal issue for me. Because we were living together in mixed villages and then suddenly the "fascists" and "liberals" (as we know them in the USA) wanted to take over the island through Greece and overthrow the president-they basically wanted to kill him. Such material struggles informed and shaped how I thought about race. One of those conversations over the war in Cyprus concerned "ethnicized" groups. And I always used to say: It cannot be possible that it is only ethnicity that makes people who were living peacefully together suddenly start to kill each other. That was a question I took to graduate school but that had been with me from a very young age because I lived through the war.

Additionally, one of my uncles would bring me lots of books, including Aris Velouchiotis (one of the major communist leaders in Greece), Frantz Fanon, and Kahlil Gibran. I was always reading these different kinds of texts that highlight Siba's [Grovogui] point: we were already part of the world in struggle; we were not a small part of the world; we were not just fighting the Cyprus struggles or the nationalist war in Cyprus. For me that living life-education and directed-engagement informed and shaped how to ask questions (see Agathangelou and Killian 2017).

I was granted a scholarship to study in the USA which allowed certain people in Cyprus to develop as intellectuals and then to bring back the knowledge. This also happened vis-à-vis the Soviet Union. And so, the money was divided by the island: some go and study communism, some go and study liberalism. Some of us tried both. But in a sense, even that decision was racially-based.

\section{Shampa Biswas}

Like most people who grew up in the Third World I came to race as a critique of developmentalism in terms of an ideology and practice. I was raised in the Indian middle class, in a lower-middle class neighborhood, densely packed with refugees from mostly west Pakistan. My family were refugees from east Pakistan. That's where I grew up, but I think that everyone who grows up now-in urban and even rural India-grows up worldly, in the sense that you always have a sense of your place in the world. So, Fidel Castro, Tito etc. were very much a part of my world.

The perception of growing up in urban India was also worldly in a different sense, which pertained to a sense of inadequacy, to be honest. I grew up with the sense that we had somewhere to go and that somewhere was someplace else; the aspiration was to do better, where better was someplace else. In Global Shadows, James Ferguson talks about a man in Lesotho who aspires to a "rectangular house", which Ferguson describes as an aspiration to a European-style house which is not necessarily well-suited to his living conditions. I recognize that desire and aspiration to be modern on someone else's terms.

\section{Sheila Nair}

I was born and raised in Malaysia, which is home to many ethnic groups, and whose ethnic divisions manifest in the economy, culture, society and politics. It is 
a country that has had to confront not only the history of colonization but its legacies of inter-ethnic difference and division. British colonialism was largely responsible for these ethnic — which typically translates as "race"- - divisions that hardened after independence. So, the question of race (and its connection with ethnicity) has been with me ever since I was an "Indian" child whose schoolmates and friends included those who identified as Chinese, Malay, or some other ethnic group. [For a symposium discussing the fraught conceptual relationship between "ethnicity" and "race" see Murji and Solomos 2016]. What's unusual, especially in comparison with other similarly ethnically divided societies in Asia and elsewhere, is that in Malaysia ethnically based parties dominate the political landscape and social and economic divisions continue to reflect the ambiguities of the post-independence "social contract" in the Malay peninsula that presumably struck an uneasy balance between political power (of the Malays) and economic power (of the Chinese). Identified as a descendant of "Indians"-although this is problematic given the different regional origins of people who emigrated from the sub-continent in late colonial rule to what was then British Malaya-my ascribed ethnic identity shaped my consciousness to some degree. Notably, on identity cards issued to all Malaysians, as well as on passports, we were identified by race, not by ethnicity.

So, I grew up with the awareness of $m y$ race in a "multi-racial" society and country. But that became a powerful motivating force for me to investigate the ways in which "race" gets constructed. It was only with more critical work in Malaysia's social sciences that "ethnicity" came to have greater sway over race in describing these social understandings and arrangements (see Nair 1999). After all, the British had tried to erase the differences within the so-called "Indian," "Chinese" and "Malay" communities in their census classifications. I was further exposed to ethnic (or racial depending on who you talk to) politics and ethnicization of the workplace when I worked for a brief period of time-about 3 and a half years-as a journalist in Kuala Lumpur.

\section{Robbie Shilliam}

[The following comments demonstrate the importance of the Anti-Apartheid movement in these various points of departure. I wanted to pay special attention to this influence because, as Paul Lauren noted some time ago, the struggle over Apartheid in the United Nations generated a set of organizational innovations. In fact, the global importance of this struggle was directly addressed by Audie Klotz and Neta Crawford in some of their work in the 1990s decade (Klotz 1995; Crawford and Klotz 1999). In contrast, many conventional histories of international organization from a Western/First World perspective presume that the UN was moribund until after the end of the Cold War.]

\section{Locksley Edmondson}

One unforgettable experience while studying and living in Britain was my participation in several anti-apartheid demonstrations against all-white segregated cricket teams 
visiting from South Africa which laid the foundations of my subsequent involvement in several other anti-apartheid activities in East Africa and especially in the United States.

\section{Randolph Persaud}

Back home in the Caribbean, the anti-Apartheid movement was a huge deal. We knew a lot about Rhodesia and South Africa and we grew up with that issue-it was so internalized.

\section{Mustapha Kamal Pasha}

I don't think I experienced race until 9/11. But as a concept and an abstraction, it goes back to the graduate years [at the University of Denver] when I was part of the international committee against racism - it was mostly about South Africa and the anti-apartheid movement. As graduate students, we had an organization pushing for divestment from South Africa. Nonetheless, race at this point was very abstract to me: it was a "long-distance" kind of category.

\section{Shampa Biswas}

I was involved in the anti-apartheid struggles in high school [in India], although I think most of that was still abstract for me also. I went on some marches. I can still sing the South African national anthem that I learned then. I admired Nelson Mandela and Steve Biko. But it was not what I would call a clear and concrete political commitment.

\section{Sheila Nair}

I still remember when, in a secondary school English literature class [in Malaysia], I was introduced to a whole lot of different writings: Shakespeare, yes, and the usual classics like James Joyce and so on, but also Alan Paton and many other writers. Paton's book- Cry the Beloved Country- came out in 1948, yet it resonated with me as a teenager. I remember feeling like my life had changed reading that book because I had now been exposed to something I only understood in the abstract. I must have been about 14 when I started reading and thinking about apartheid. It was not unusual for a middle-class kid like me going to one of the best public schools in the city to be debating with classmates the problem of apartheid. I think for many young Malaysians, "race" and racial oppression in that context meant something very different than the experience of racial difference in Malaysia. 


\section{Movements}

\section{Shampa Biswas}

I think many of us might have come to a consciousness of race through travel. That's certainly the case for me. I grew up very much with a sense of being dark and of not being upper-caste. And at some point, those two things connected in some sense. There has been some contestation in my family about how far down the caste hierarchy we really are, or how much we are trying not to be as lowercaste as we really are. But that sense of being sort-of-dark has always stayed with me. It became politicized in a very different way when I travelled to the USA.

So, it's important to consider how color itself travels across spaces. Certainly, many within the Indian diaspora who move to spaces like the UK or US come to see themselves as racialized. But that moment is often politicized by marking oneself as different from and better than certain other racialized groups. There are many examples of Indians in the southwest of the US especially, who take on an Indian identity - wear a saree, put on a bindi-to mark themselves as different from Hispanics or Latinx immigrants. In this respect, being racialized doesn't necessarily lead to a critical consciousness of race as positionality, or to relations of solidarity with other racialized groups. I want us to think about how these two moments connect, how they remain separate, and why they go in different directions.

\section{Sheila Nair}

I came to the USA from Malaysia to undertake my undergraduate and subsequently, my Masters degrees at the University of South Carolina in the mid-1980s. Living in the south meant that overt and covert forms of racism were inescapable. I arrived in South Carolina as a transfer student from a small college in North Carolina where I had spent a summer, and was assigned to a dorm that at the time housed mostly African-American students. Being very much a part of that community was informative for me in terms of navigating race politics in the South. That was also something that influenced my own consciousness and awareness of what Black Americans had endured and continued to endure. It was an eye opener for someone like me who had no context to place this American experience to see how that kind of segregation functioned and how even in-what at first glance appeared to be-a de-segregated campus community, race and residency were unquestioningly linked.

\section{Mustapha Kamal Pasha}

My first encounter with actual racism was when I came to Britain in 1979, two years before the Brixton uprisings, and I made friends with Americans and people from the Caribbean. I had one friend who wanted to go and fight with the racists. That was the first encounter of the racialized formation that was Britain. 
However, in the USA, because of the colonial background that I came from, I never saw racism until 9/11. [Commonwealth immigration to Britain in the 1950s and 1960s featured a predominance of both Caribbean and South Asian peoples, such that visceral racism was directed (albeit for slightly different reasons) to both sets of Commonwealth British citizens]. And I think Shampa's example demonstrates why people coming to the USA from India for instance, or from South Asia in general, choose to project a certain kind of identity. This is a lot to do with the kind of negotiations they have, first with the dominant population, but also with others who are not dominant. So, I want to problematize the binary between white and black. There is a sense in which color is the important marker.

\section{Shirin M. Rai}

When I came to Cambridge in the mid-1980s I engaged with all these internationalist groups-Brazilians, Colombians, Australians and South Africans, Pisco Sours [a Peruvian cocktail] in hand and a lot of political conversations and arguments. For me it was a wonderful phase in my life. One thing that did, of course, worry me in the UK was the hinterland of migration. Most of the Indian diaspora here came in the late 1940s and early 1950s as laborers — many from the villages of Punjab — and experienced terrible racism, which was absent from view (although no doubt present) in the halls in Cambridge. Class matters.

But so did location-I never thought of myself as an "ethnic minority" and of course I was not British then. Becoming Black [in the sense of "political blackness"], and then becoming BAME [Black, Asian and Minority Ethnic - an administrative term consonant with "people of color"] has been a long and complex journey, which I have still not finished. A little while ago I was chatting with a colleague at Warwick University. I said "I used to call myself black but I supposed I should now call myself BAME"; and she replied "you are not! You are not going to call yourself BAME". I asked why not, and she said "well, you didn't grow up here; you have no experience of racism on the playground or on the street".

\section{Locksley Edmondson}

Shortly after earning my Bachelor of Social Sciences, Honours Degree (Economics, Politics, Sociology) at the University of Birmingham (1960), I moved to Canada for my graduate studies financed by a Fellowship Award at Queen's University, Kingston, Ontario, where I first earned a Masters degree in Political Studies (1965) by completing a thesis about the United Nations Trusteeship System which enhanced my knowledge of colonialism. I postponed completing my PhD dissertation at Queen's University until 1973 after serving the following appointments: Assistant Professor in Political Science, University of Waterloo, Canada (1963-1967); Visiting Lecturer, Department of Political Science, Makerere University, Uganda (1967-1970); Assistant Professor in the Department of Government, Cornell University (1970-1973); Visiting Associate Professor, Graduate School of International Studies and Acting Director, Center on 
International Race Relations, University of Denver (September 1972-January 1973), on leave from Cornell University.

Of the above appointments, my 1967-1970 stint as Visiting Lecturer at Makerere University located in Uganda (as part of the University of East Africa) was the most instrumental in my pioneering work in the field of international race relations [see for example "The Internationalization of Black Power" (Edmondson 1968), first published in Makerere's journal Mazawo]. Here is how it began.

While employed at the University of Waterloo in Canada, I travelled to the United States to attend the annual meeting of the American Political Science Association in the early-mid 1960s. On walking into the hotel dining room for breakfast, I saw three Black men seated at one table and decided to join them. One of them introduced himself as Ali A. Mazrui, then an academic star among African political scientists. He invited me to join him for dinner later that evening. He began asking about my academic interests, and if I had ever visited Africa, I replied that I had never visited Africa and then queried why he asked. Mazrui replied that he was Chair of Political Studies Department at Makerere University and was searching for someone to fill a teaching position to replace a colleague who had recently left the university and that "I think that you are the person I would like to fill that vacant position." I replied that I was very interested and within less than 6 months I was on my way to Uganda along with my family, with my visit being funded by the Ford Foundation which Mazrui had orchestrated. I spent the next 2 years teaching and researching at Makerere.

The late 1960s was a period of heightened and heightening Black racial consciousness, best articulated under the slogan of "Black Power" (see Edmondson 1969). This too was the period in which the apartheid system (which was thriving with the support of other countries, very much including the United States) was also being increasingly challenged.

\section{Randolph Persaud}

I went to Canada in 1977. At that time, there was an enormous amount of racism against people of color, but especially against South Asians. It was called "Paki-bashing". It was often violent. This is partly why, when people talk about violence without its physicality-for instance, "epistemological violence"-I tend to silently protest. I know there might be a lot of quarrels with that judgment. But at that time in Canada, for South Asian looking people and Black folks from the Caribbean, especially Jamaicans, racial discrimination, often armed, was too traumatic to use violence lightly. So, racism in that sense is very real to me. Sometimes I write about racism in a very expressive way because that's how I came to encounter it—not so much from reading books etc. 


\section{Graduate school}

\section{Rob Walker}

It is now difficult to imagine how, back in the mid-1970s, analyses of international relations were shaped by categories of North, South, East and West: by Cold War and Development. In my view, North-South was and remains primary. Theories of international relations express a philosophy of developmental history, of temporality, that is then played out in geopolitical space. At least, this is how I have tried to make sense of IR as a discipline, one that I don't really inhabit. I work as a political theorist, with considerable background in early-modern European conceptions of science and their expression in thinkers like Hobbes and Kant. This gives me many advantages for thinking about the contemporary politics of knowledge. For me, IR is an object of analysis, an expression of how one is now encouraged to think about the world and the kind of politics that is possible and impossible within it.

But sometimes I have been sucked into that discipline. The crucial time was when I turned up at Princeton, primarily because of Richard Falk. Many very smart people, nice people too; but a pervasive culture of racism was tangible to me, along with the presence of enormous state power. I learnt a lot from the experience.

More importantly, Richard brought me into the World Order Models Project (WOMP), the great forgotten site of interesting thinking in IR in the 1970s and 1980s. Quite apart from the extraordinary intellectual range and cultural diversity of many of the people involved, it was especially interesting for me as an expression of the contrast between people preoccupied by questions about East and West, and thus peace, and those more concerned with North and South, and thus development, colonialism and so on (see Walker 1984). I am not averse to peace, but tended to have more in common with figures like Rajni Kothari, Ashis Nandy, Dhirubhai Sheth, Mohammed Sid Ahmed, Ali Mazrui, Yoshi Sakamoto, Vandana Shiva, Lester Ruiz and many others in many countries. As a travelling seminar, WOMP was a model for transversal conversations that could usefully be replicated now that we seem to have retreated into our little boxes, both politically and intellectually.

In any case, it was out of this background that I began to start editing the journal Alternatives, which took up most of my time for three decades and gave me privileged access into how people were thinking politically beyond the secured enclaves of American social science.

Instructively, I think, many of our discussions in WOMP hinged on questions about "culture," understood as an acceptable category encompassing many other less acceptable things, from race to religion. Yet while culture was in some ways the acceptable discourse of the Cold War era, it was also easily reduced to nationalism, the claim to identity that could trump all other claims to identity, including humanity. I think that this remains a problem in many contexts. WOMP was certainly not alone in challenging many of the conventions of the discipline as it 
then was, and questions about race were raised in various contexts with some frequency. Whether they were or even could be raised frequently enough, or sharply enough, is another matter. But the problem was not limited to any specific discipline. Even the concept of a society is difficult to disentangle from what statist nationalisms say a society must be, and any attempt to differentiate the various peoples to be found in any society will be subject to nationalizing practices of homogenization and hegemony and/or domination. As usual, the discipline is largely an effect of something much bigger and much more difficult to deal with.

\section{Shampa Biswas}

The biggest culture shock I experienced upon coming to the USA was the confidence about the country's place in the world. Even in progressive circles, the desire is almost always to be a better version of yourself, not an aspiration to be someone else as it is for those in the Third World. And that self-referentiality sort of mimics some of the MAGA [Make America Great Again] narratives. In contrast, I grew up with the aspiration to enter another world. That took me to economics-neoclassical economics no less. I wanted to become a development economist. I very much bought into modernization theory, or even if I wasn't consciously buying into it, it was the background condition of my desires and aspirations. It was very much economics as a technique, what Ferguson calls an anti-politics machine.

And it took 4 years-I got two masters degrees [at the Delhi School of Economics, and Syracuse University] in the process - to be able to see economics as a racist discipline, to see its representation of me and my people as always hungry, empty, takers and not givers, to not be able to see the world that I lived represented in the discipline. It took years. I actually credit Naeem [Inayatullah] who was my teacher [at Syracuse], with helping me get there. But once I got there, and that was to an understanding of economics and developmentalism as a racialized discourse, I was not able to un-see it.

People ask me if I regret spending all that time in economics, trying to be what I no longer wanted to be. I don't. I learnt a lot from it, and it gave me respect for the fight ahead, for how much is at stake in keeping that discourse alive. And it led me to interdisciplinarity as common-sense. So, for instance, I find what I want to study because I am interested in problems in the world and not because it has anything to do with IR. In fact, I don't even go and read IR scholars to see what others have said before on that topic_-that's not my impulse at all. And it really doesn't matter what I pick as a topic of study, race is the background structure and the material condition that helps me understand that topic as a problematic.

\section{Sankaran Krishna}

My undergraduate degree was in chemistry, with math and physics as my minors. Then I went into the History program at Jawaharlal Nehru University, which at that time and for a long time afterwards was probably one of the greatest places to study in the world. This was a Center that could hold its own against anything that 
you could put it up against, and I just stumbled into it with a chemistry degree. Through sheer luck I got into the program, and it just completely transformed me. Above all, it brought out the utter centrality of colonialism, imperialism, and racism in the creation of the modern world. It was really all about that post-1492 moment, the Atlantic slave trade, the conquest of the world, Eurocentrism, etc.

So, with that background I arrive at Syracuse University in the USA. And for the first time ever I am in a Political Science program with the intention of doing a dissertation in this field called IR. I have to tell you that the combined total of books that I had read in IR up until that point was zero, and in Political Science, maybe two.

And I just want to talk very briefly at a social level-an ethnography of my first few weeks in the USA. Political Science was full of these guys who were very macho because they were supposedly very good in methods. Methodology was incredibly fetishized and these guys were literally strutting around because they were very good at doing regression analysis etc. Some of them would go for a run in the afternoon; they would play basketball with the rule-no blood, no foul. A very macho culture: and it was all about method. I had always thought of method as a means to an end, but here clearly method was the end. And anyone who dabbled in history, who was interested in qualitative approaches, well you were deemed to be an inferior being.

Now I had one advantage, which is I actually knew my math-I had taken math and physics as minors-and I could hold my own against anybody. So, these guys were faced with a problem: "here is this brown-skinned guy who is very much into colonialism, imperialism, racism, soft, qualitative methods and all the rest of it, but who can ace the math and the stats and the method course as well as anybody, if not more". I began to harass my professors by saying: "before we start measuring the extent to which two things depart from a linear relationship to each other, can we please stop and ask why the **** do we think they might have a linear relationship with each other?". And, "why do you think that the world is organized along some orderly set of premises? Where do you get this illusion? And might that illusion itself be a violent interpretation of the world?" The response would always be: "you know, maybe you should do some course in the philosophy department, because we don't do that here. We start on the premises that they do have this relationship and now we want to see how much they depart from that".

\section{Anna M. Agathangelou}

When I arrived at Syracuse University I wanted to learn why people killed each other. Some of my interlocutors took that to mean "those ethnic wars out there". Immediately, then, Cyprus became an ethnic conflict-as if it wasn't a global war, as if it wasn't part of a contestation of global powers. Yet when it came to IR specifically, the approach was "let's divide the knowledge" i.e. focus on case studies. Meanwhile, the abstract theorists told us how to apply their knowledge 
to really explain those conflicts and wars without ever accounting for how those sites themselves were implicated in the global production of knowledge and in the global color line.

One of my big struggles during the $\mathrm{PhD}$ occurred during my dissertation. I worked with Mark Rupert who was, of course, an expert on Gramsci. I wanted to use Gramsci but I also wanted to use feminist postcolonial analyses of the conflicts and the war. And around that time, many of us in the department agreed that we needed more than was being provided if we were to understand what was going on elsewhere in the world. So, the Political Science department sent us to explore different departments-English, Women Studies etc. But some of us got together on our own and started reading texts such as WEB Du Bois, Malcolm X, and Frantz Fanon. Still, our department in Political Science and IR did not think that these texts were central and pivotal to a politics and IR curriculum.

\section{Roxanne Doty}

Politically and academically, my main concern was colonialism-rich country, poor country relations. My dissertation was focused on inequality and hierarchy, and who has power over whom. I started investigating various specific cases of colonialism and of course, in doing so you are going to run into race. So that was my first academic experience. Like most of mainstream IR, race was never a thing that was brought up. Well, I wanted to investigate how race worked in a very disguised and coded way into IR scholarship and current policy issues. That was all back in the old days of my dissertation.

After I finished the dissertation, I was left outraged by the discourses of colonial power even in early IR scholarship, as well as what was contemporary at that time (in the late 1980s and early 1990s). And then I wanted to know, "has race disappeared now? Where is it lurking?" That's when I got interested in borders and immigration. You can't talk about borders and immigration-especially if you are talking about unauthorized immigration-without race immediately smacking you right in the face. So, I became interested in those issues.

\section{Sheila Nair}

I was at the University of Minnesota around the time that Roxanne [Doty] was finishing her $\mathrm{PhD}$ there. Her dissertation work on racial representation and imperialism made an impact on me. Additionally, Bud Duvall created a space for us to engage with issues of race and colonialism. I recall that when I took his International Hierarchies course (it might have been in my 2nd year) he told us something along the lines of: "I don't really have a syllabus; I have a few things on it right now, but feel free to contribute to this." I suggested we include Spivak's essay "Can the Subaltern Speak?". I was struggling with this piece and trying to figure out what she was trying to say. Spivak writes in a way such that sometimes you think you have arrived at comprehension but you soon realize that you haven't got a clue. I struggled a lot with it and I wanted to bring it to the seminar so that I could understand it better. 
I think she forced us to question race, gender, class and the subaltern in ways that generated a productive intellectual tension. For me that was a really important work in terms of coming to grips with where I saw my own work going (or not going). I would say that this is when I began thinking more about race, its intersections, and postcolonial theory.

\section{Errol Henderson}

The first thing I did in September 1986, when I started graduate studies at the University of Michigan, was to join the Black Student Union. There was already a buzz on campus-free South Africa groups etc. But when racists put a flyer under the door where some sisters were meeting, saying that it was open season on "porch monkeys" and " $n * * * * s "$, and when racists got on the radio and told racist "jokes" we started the United Coalition Against Racism-a multi-racial coalition, but Black led. However, the Black fraternities, sororities, and student unions were also organizing and ended up coming together as the Black Action Movement III. [There were two prior moments of Black student protest at Michigan in 1970 and 1975.] The first statement of BAM III was to support all the demands made by UCAR. But BAM III had other demands - and quite simply, BAM III were more oriented to specific black demands and organization. I worked with both UCAR and BAM. By spring 1987, we brought in Jesse Jackson to mediate our demands with the University of Michigan. Following UCAR/BAM III, through the Black Student Union, we started organizing Black student unions in local high schools and projects.

My focus was on black nationalism - unrepentantly. Post-structuralism and similar bodies of thought will take issue with the universalizing tendencies of white supremacism - and rightly so-but then they'll replicate that tendency when it comes to judging nationalism - in whatever historical context - to be unprogressive. Well it depends. The nationalism against colonialism can be quite progressive and even revolutionary. African American nationalism is not a derivative of American or any other nationalism-Wilson Moses' research demonstrates that. Let me say this: some people might be more likely to push "black" when it's more fashionable to do so; some of us, who work with diverse folks as well, still focus on "black" even when it's not fashionable to do so. Much of the "conflict" over black nationalism among black academics is really about class. I'm from a housing project and I've been in a union since I was 19, and my perspectives born of that, as well as my organizing and study, challenges some black folks positioning themselves in academia as "grassroots"-at least that's what it was like during my graduate studies at Michigan. They can only imagine the black poor whose interests they presumably "represent" because for so many of them it's never been their reality or the basis of their activism.

Anyway, whilst all this was going on I was studying with Ali Mazrui and David Singer and his Correlates of War (COW) project. I went to Singer because this notion of doing quantitative work intrigued me. But some people told me that Singer didn't support Black Studies. So, I walked over to his office and asked him. He responded: “well Henderson, I didn't support Black Studies because I thought it 
would be ghettoized". It seemed a rational response to me-especially since it was ghettoized when I got to Michigan. We then discussed the intellectual and strategic reasons for scholars like him to support Black Studies; and it was a serious engagement between us. When it ended, Singer said: "I made a mistake". By the end of that first semester in 1986, he invited me to the COW project, and I've been a member ever since.

Singer would also talk to me about the anti-Semitism he dealt with growing up in Brooklyn and working as a haberdasher in North Carolina. You can't reduce people to their writing, you know. He's got a critical sensibility that he would associate with his Brooklyn background to me. I asked Singer what made him get into the quantitative work, and he said to me that following WWII (Singer was in the US Navy but not in combat), and what he thought was the tragic and racist atomic bombing of Japan, he realized that scholars couldn't leave foreign policy decisionmakers to diplomats, philosophers and historians. Instead we needed to draw on more reliable and systematic evidence to provide reasoned diplomacy to prevent a future World War, which he was convinced would be a nuclear holocaust for humanity. He turned to broad and depthful analysis of history as a starting point, and then drew on computer technology to evaluate common notions about the correlates of war-in order to prevent them. Singer lost his security clearance because he spoke out against the Vietnam War in the early 1960s. Tom Hayden was one of Singer's student and Singer supported the early teach-ins against US involvement at Michigan in the early 1960s.

And that's why I say to people: your methodology is not your freaking identity! You mean to say that you're upset because Singer wants to do something quantitative (see for example Henderson and Tucker 2001)? That's why I also always bring up WEB Du Bois and his quantitative analysis in the pathbreaking Philadelphia Negro. The basic question in grad school for me was: who can you grow with intellectually and who can encourage you in your chosen academic (and activist) directions? They are not mutually exclusive. Singer was one of those people-so was Ali Mazrui, Ken Organski, Harold Cruse, Clementine Barfield and Hanes Walton. When a black administrator took my fellowship in order to force me to leave grad school and hopefully end my activism on campus, Singer, at my request, called him: my fellowship was restored the same day.

\section{Neta Crawford}

I was part of a very loose cohort of people doing critical IR at a time when the most important debate was responding to Kenneth Waltz's Theory of International Politics. To me, that was a relatively closed and sterile debate, and much more interesting things were happening in scholarship and in the actual world. The metatheoretical debates were about agent and structure, but they were not about processes. I was interested in change, and the ways in which big sweeps of history could help you to better understand processes. I wanted to be part of a different conversation about colonialization, decolonization and militarization.

All my life I've been interested in African politics-my undergraduate honors thesis was on military rule in Ghana and the era from Kwame Nkrumah to Jerry 
Rawlings. But actually, I started to work on Native American international relations a couple of years before I started my work on decolonization and humanitarian intervention (see Crawford 2002). And I have also always been interested in Native American politics, perhaps because I grew up in Wisconsin, perhaps because some of my distant ancestors are native, perhaps because being in the Northeast of the US [initially pursuing graduate degrees at MIT] I became aware of the Iroquois League [the Haudenosaunee confederacy].

It all came together for me when I read that the concert of Europe was a very longlasting security regime-125 years. Well, the Iroquois League ensured 450 years of peace. It began before European occupation of the Americas, it lasted hundreds of years through colonialism, and it was only disrupted by the American revolution. And, by the way, growing up in the Midwest I knew of other such leagues like the Ohio Confederacy. To be clear: these were leagues of peace, not alliances against someone else.

This is what I was learning about in the early/mid 1980s and all through my graduate education I continued an interest in this. I took a class with Stanley Hoffman \& Robert Keohane at Harvard on theories of international relations. It was excellent in its own way, but I felt that it was ahistorical and lacking a comparative perspectiveas if there was no other perspective but the Eurocentric one. I wrote a paper for them on the Iroquois League as a security regime; they didn't like it. So I decided to write a longer paper that was eventually published in International Organization entitled "A security regime among democracies: cooperation among Iroquois nations" (1994).

\section{Formative experiences of the field}

\section{Robert Vitalis}

My reasons for writing White World Order, Black Power Politics (2015) were 90\% instrumental and opportunist; except that, like most academics, I am not very good at being instrumental or opportunist. And it was maybe $10 \%$ intellectual curiosity.

But the book is an accident of Clark University, and the intellectual curiosity was a question that Cynthia Enloe has taken on: the Curious Feminist etc. Cynthia had hired me to teach IR. I was a scholar of the Middle East and I worked on the comparative political economy of development. I wrote my first book on Egypt, and I was interested in "false" debates of the notion of a national capitalist class. That's what I worked on in Egypt.

The instrumental part comes from the fact that after writing the book on Egypt, I had started to write a book on Saudi Arabia. I was teaching at Texas at the time along with my wife. I loved Texas, my wife hated it. She got hired at Princeton. It was time for me to move based on her preference, and the closest I could come was Clark University in Western Massachusetts. I got there in 1990, thinking I was writing this book about Saudi Arabia, and trying to find a job so that I could be closer to my wife. This is the irony: there were no jobs in the field of Middle East studies in the early 1990s, though it might be difficult to imagine in hindsight. The Ivy 
Leagues were getting rid of their senior Middle East scholars and area studies was irrelevant.

At Clark, I did what I describe in my book. I was in the library stacks one day and I happened to look at the history of Clark University. I saw this claim that the Journal of Race Development was the first journal in IR and I said "no no no, that's crazy". I had taken one IR class in my life as a graduate student with Hayward Alker. I got a B, but I do remember the disciplinary story claiming that the first journal of IR was Foreign Affairs. So, this historian at Clark was clearly wrong-because we knew the truth, right?

The curiosity part was following that through and also trying to figure out who WEB Du Bois was, because Du Bois was on the editorial board. Meanwhile, Clark didn't care about disciplinary labels, in fact they told me "you can't teach any Middle East politics, just teach IR". I taught a course with a historian on Du Bois, to try to know more about him. And then I had this crazy idea: being that there were no jobs in the Middle East, clearly it would have been smarter to try to get hired working on race in IR. I applied for a two-year retraining grant in IR, critical IR and security so as to work on this project. God bless Rob Walker, because if it wasn't for him, and two other people, the book would have never been written. I was given the one-year consolation award. Half the people thought it was the stupidest project in the world; a few people thought I deserved some money, and god bless you.

I started to work on the book when I was called to the University of Pennsylvania to run their Middle East Center. So, I had to put aside all the research I had been doing on race in IR and disciplinary history, and give a job talk about Saudi Arabia. But the funny thing is that if you look at that book, America's Kingdom (2007), you will see that DuBois is all over it, and racism is all over it, because I had learned a lot and deployed that learning in the writing about United States on the oil frontiers. In any case, now I was at the University of Pennsylvania, were I was told I could not teach IR because being a Middle East person I apparently had no connection to IR. And when I would talk to IR colleagues about race in IR their only response would be, over and over again: "are you calling us racists?!".

This was their reaction to the research, and that was in the early 2000s. When I presented White World Order to my colleagues around 2015, they raised the question: "this is all well and good, the history... but what are the testable hypotheses? You tell us that, and then we have a book that we can talk about". And that's what explains the very last lines in my book that sort of say: "some smart person is going to ask, what are the implications for theory?" And that's why in the book I say that that's not the question that is important. The important question is: what does it tell us about the classroom and the professional associations in the discipline?"

I teach race in IR, every now and again, and the empirical fact that emerged the first time I taught it, and remains the case, is that it is the only class I teach as a seminar that draws $50 \%$ or more people of color, which barely happens in Political Science departments when you teach race in American Politics. So, I am still not a part of the IR group. But here's the funny thing: nor are any of you, at least on the syllabi. Literally last night I had to have a conversation with graduate students about decolonizing the discipline, and "what about race in the discipline" etc. But from their perspective, it's still realism and idealism, etc. So the struggle continues. 
In the very first article I published in Millennium, "The Graceful and Generous Liberal Gesture: Making Racism Invisible in American International Relations" (Vitalis 2000), the only person in this conversation that we are now having and which I thanked is Audie Klotz, because I talked to her about the paper and she gave me comments. Obviously, in the years since 2000, I've gotten to know all of you and I try to celebrate the many paths that you, men and women, had forged in the field.

In a way, I would say all of you —although you might not have known it-were following in the footsteps of folks like Locksley [Edmondson], folks that Roxanne [Doty] notices. Roxanne writes her piece "The Bounds of 'Race' in International Relations" (Doty 1993b) and sort of says: "hey look at this thing going on in Denver, right?". Karl Deutsch was there [at the Center of International Race Relations at the University of Denver], and Locksley Edmondson was there [see above], and George Shepard was there. They themselves were effectively saying: "we're doing this for the first time; finally we are going to talk about race systematically in IR, because guys like Stanley Hoffman have failed to do it." That's their reference at the time. In a way, you have all been following through on that project. (Others, such as Tilden LeMelle got moved into other directions.)

I think it is not accidental that gender becomes more visible in IR as more women enter the field and raise those questions. But in the same time period, race is not as visible and the question is not raised as much because there are not a lot of people of color joining the field - and that is still the case in some sense. In any case, I wonder if folks knew what Locksley Edmondson and George Shephard were doing in the 1970s, effectively declaring that "hey, you know, racism has not disappeared from international relations, we need to explore it." The folks in this conversation now also started doing exactly that.

\section{Mustapha Kamal Pasha}

Well, thanks Bob [Vitalis] for mentioning George Shephard, who was my professor while I was a graduate student in Denver. I think he was one of the pioneers in International Relations when it comes to talking about race and Africa. But I did not take a class on race with him; I took a class on Africa. In fact, for me, race came via Africa-it came via Apartheid. For some of us, our introduction to race was through transnational consciousness. It was from outside in, not inside out. It came from these connectivities with the anti-Apartheid movement.

In IR itself, I think the most important influences in the more recent past are Randolph Persaud and Sankaran Krishna. Krishna (1993) wrote one of the first significant articles on taking to task the field for its treatment of race. And then of course, the special issue in Alternatives that Randolph edited was quite important too (Persaud and Walker 2001). Randolph was one of the first persons to bring the idea of race to American University which was ultimately the liberal university. [Ron Walters, a prominent Political Scientist and co-founder of TransAfrica had in fact earned his $\mathrm{PhD}$ in International Studies at American in 1971 but left thereafter.] And I would also consider him one of the pioneers in re-starting this conversation within international political economy (see Persaud 2001). Working with the scholarship of 
Robert Cox, Randolph would very politely unpack those categories and make them look pretty mechanistic and static.

Moving forward, other influences come to bear. Siba Grovogui, of course, has been crucial in bringing Africa to IR, but in a way that affirms confidence in thinking of another place from a position of parity. That has been the most important part: not to feel in anyway diminished in talking about these "Third World" places.

\section{Randolph Persaud}

Well, I went to the ISA annual conference in April of 1995 where I presented a paper under the title "Frantz Fanon, race, and world order" (Persaud 1997). After the paper was finished, Mustapha [Kamal Pasha] informed me of a job at American University. I joined the School of International Service later that year in the fall semester. When the ISA was held at Minneapolis in the Spring of 1998, I met Sheila [Nair], Shampa [Biswas] and others. Somebody pointed Rob Walker out to me. I approached him and told him that there was no special issue on race in IR in any of the journals, and asked him to consider taking a look at a proposal. I had also just met [Sankaran] Krishna and Siba [Grovogui]. Siba and I had gone to a previous ISA meeting in New York.

And that's how the Alternatives special issue on race in IR came together, involving all of these scholars. The only person not here from the special issue is Hilbourne Watson (Bucknell University) who contributed a fine paper on race and the historical political economy of the Caribbean. Crucially, all this means that I didn't discover race in IR on my own. The collaboration, encouragement, and working together: that really made an indelible imprint in terms of the questions that I began to pose analytically and the way that I thought things through theoretically.

\section{Sankaran Krishna}

If Political Science was deeply conservative and obsessed with methodology, IR was the most concentrated form of that. Still, when I went to the ISA annual conference, at least I felt like a resident alien; but when I went to the APSA [American Political Science Association] conference, I felt like an extraterrestrial-I wasn't even a life form from this planet. Weirdly enough, the ISA at least gave you some kind of hope, whereas American Political Science with this mixture of machismo, methods-and there should be a third M there, but I don't know what it is! - left you in despair.

I also realized that this all hung together because Political Science departments thought of themselves as liberal. Most of the faculty voted Democratic. So that's how this thing played itself out: "we must be good on race, we must be good on liberal values, because we vote Democrat; the real conservatives are those guys out there who vote Republican, whom we don't have any of'. It took me a while to realize that all the codewords about theory building-conceptual rigor, abstraction, a distaste for history, particularity and context - all of these were coded words for not dealing with race. That's how IR constructs itself: it's not about what it says but 
about what it doesn't say. Race is the absence that coheres the discipline, and it takes you a while to put your finger on it.

So, I decided fairly early on that mainstream IR and Political Science for the most part, at least the American idea of it, were completely lost causes. The only fringe of IR that I was interested in were the "posties": guys like Rob Walker, Rick Ashley, Bill Connolly, Mike Shapiro, David Campbell-that whole crowd. I began to hang out with them. Weirdly enough, my first critique of the absence of race in IR was on the absence of race in postie-IR — in the only scholarly group that was worth talking to at all.

Soon after I joined Manoa [University of Hawai'i], I took a course with Rob Walker at the International Semiotics Institute. Rob said: "hey listen, there are these four books that have just come out-Bill Chaloupka's Knowing Nukes, James Der Derian's On Diplomacy, David Campbell's Writing Security and Mike Shapiro's Reading the Postmodern Polity". Rob suggested I write a review essay on them, which instead became a 13,000-word piece about how critical IR has this serious racial amnesia, how it's a sort of transatlantic dialogue wherein the North American crowd seems to think that if you bring in more of Foucault, Derrida, or whoever, you have something going on. But race was still marginal even to the "posties", in my view.

After writing "The Importance of Being Ironic" (1993), I went back to my disinterest in IR until about 8-9 years later Randolph [Persaud] asked me to write a piece for the special issue on race and IR. I wrote mine on race amnesia and the education of IR (Krishna 2001). But for all the claims in both my essays about the absence of race in IR-well, that wasn't an empirically sustainable claim but more a reflection of my ignorance of the history of IR. Because, as Locksley's [Edmondson] work testifies to, and as the recent works of people like Bob Vitalis, John Hobson, Robbie Shilliam and a whole bunch of others show, race has always been written about in IR. It's just that anytime anybody used the word race, they were excluded from the club. WEB Du Bois was of course the classic example of that. Two years before Lenin's Imperialism the Highest Stage of Capitalism Du Bois had already argued that inter-imperial rivalry was the stream that flowed into making the Great War. Yet Du Bois is never thought of as "doing" IR. The Howard school is, again, excluded from the canonical discipline simply by an act of fiat.

\section{Roxanne Doty}

I don't like to say I'm a scholar of race, and I have sort of positioned myself on the periphery. In my very first published article in $I S Q$, "Foreign Policy as Social Construction: A Post-positivist Analysis of US Counterinsurgency Policy in the Philippines" (Doty 1993a), I bent over backwards to explain and justify and speak and please the mainstream. That's probably the article that gets cited more than anything, and honestly, I came to feel uncomfortable about it. There's a section on research design, there are tables, and everything is wrapped up neatly. I would be invited to discourse analysis panels-I'm not putting this down at all, I don't mean it to be critical of what anybody does - and I'd have graduate students asking "how 
did you do this? I want to use your method". I came to feel very uncomfortable and never wanted to write like that again. In any case, I got tenure and I didn't have to communicate with the mainstream anymore.

\section{Shirin M. Rai}

I went to my first ISA annual conference very late because I had kids and I didn't want to travel. The first time I attended was in 1997, less than 10 years after I started, and that's when I saw race scholarship in action. I then got involved with the International Feminist Journal of Politics (IFJP)_- I am remembering Lily Ling and Geeta Chowdhry here (see especially Chowdhry and Ling 2018). We raised issues of difference and of diversity on IFJP board meetings. And some of them were actually painful_-personally painful_-because you had to raise issues which were seen to be disruptive and not really central to what was being discussed. It was always the same three women who were raising these issues. But we had fun as well.

At ISA we all engaged in the struggles against structural racism. Yet ISA held sadness for me as well. Because I would go to gender stream panels-I research the political economy of development and gender (for example Rai 2002) - and there would not be enough race, and then I would go to postcolonial race panels and there would not be enough gender. What the hell! Why are these literatures, people-my colleagues - not working together? That has bothered me quite a bit and I think it was out of that that Geeta and I wrote "The Geographies of Exclusion and the Politics of Inclusion: Race-based Exclusions in the Teaching of International Relations" (Chowdhry and Rai 2009). And that was really good for me, because even though I am not a race scholar, it allowed me to think through some of those issues.

\section{Anna M. Agathangelou}

Shirin [Rai] has brought this very important issue up. Mustapha [Kamal Pasha] was actually the first person who suggested that I go to the Feminist Theory and Gender Studies (FTGS) section, which was a really important space. Lily [Ling] and I started to do a lot of work around race because she had her own struggles around the tenure situation, which was already based on racial questions and gender issues. We also grappled with FTGS. Not that ISA is the panacea of everything. But ISA remains a site of struggle for thinking race, gender, sexuality, ability, etc. It is a site that I think a lot of our students, especially those from marginalized communities, can see others grappling with similar issues, and building intellectual frameworks that might help to think through some of those issues in IR and in their own lives.

Thanks to Mustapha for his suggestion. Thanks to Lily and Geeta [Chowdhry] also. Around 2006, the four of us-Lily, Geeta, Sheila [Nair] and myself-toured Asia, talking about the feminist postcolonial, moving those knowledges rather than always bringing everything to the West, to the ISA, which is a very Western institution. 


\section{Intersectionality}

\section{Randolph Persaud}

On this note, I would really like us to talk about what we think the "back-stop" of race is. I think one of the unfortunate things that's happened, with the rise especially of some aspects of discourse analysis, is that the body gets suppressed. And for me, racism is a very optical kind of thing: what kind of body do you see-what kind of hair, lips, color etc.? There's enormous variation in that. So, the body can save you the farther you move away from certain configurations of the Other, and the body can endanger you the closer to get to that Other.

That's something I really want to talk about. And I think color gets pushed aside a lot in racism, because even among, say, the black community it's like literally: how black? I do know that the body is ultimately a discursive outcome. The physical body might not have any inherent meaning in it, but the body does have a history to it as well. I struggle with that: the body you carry around with you, and the way in which meaning might be imbued in the body or derived from it.

That's why race, to me, is about the ontology of the body. In a conversation such as we are having, I have several options of how to construct what I want to say. But I have no absolute self-governance over this body. While the body is a floating signifier, it does have a history to which it has been subjected. That is a huge difference. For instance, and Siba mentioned this, presenting the Irish as "racialized" as white is a construction that I have some problems with. At least, I am wary of the way it can be coopted by liberal discourse so as to not really talk about racism because everything is racialized. Which means that practically anything could be, so to speak, subsumed under a broad category called racism - which I have my doubts about.

So, in this particular respect, I have a methodological problem and a political problem with intersectionality. Let me just go with the second one first. Intersectionality began as a conceptual tool to begin to understand particular configurations of exploitation and domination. It has been coopted by liberal cosmopolitanism and big-tent politics. I take the problem from a different angle, mostly from Laclau, and Laclau and Mouffe. If you construct a signifying chain, based on multiple instances of the signifying chain inter-sectionally, every time you do that, you have to compromise on the specificity of each element of the chain. For there to be lateral expansion of the signifying chain, each instance must be relaxed somewhat.

And this is what has been happening with big-tent democratic politics, which is actually in my view, forcing academics to incorporate more and more elements into the intersectional configuration. The brutalities of race and also of gender (see Persaud 2015) keep getting pushed back and back and back, to accommodate more and more things that the liberal cosmopolitan context is supposed to be/ wants. That does not mean we should ignore the amalgam of other social injuries out there, but intersectionality is becoming too much of a matter of habit, a kind of obligation of the left, almost a ritual.

Conceptually, I would prefer over-determination rather than intersectionality; at the very least, the current use of intersectionality is far removed from what was 
originally intended by Kimberlé Crenshaw. Over-determination gives us an idea of the condensation of different sort of instances that begin to congeal around particular bodies. But these are not separate instances-race is not over here, and class over here and gender over here-right? Rather, they are all configured and condensed into a particular moment of historical structure.

\section{Audie Klotz}

I'm going back to the autobiographical beginnings of this conversation to respond to Randolph [Persaud]. I take your points on the physicality, but I don't see the connection to rejecting intersectionality. As a woman, I would associate a lot of the things that you mentioned with perceptions of women, based on many of those same physical characteristics. So, I think it's actually an argument for further unpacking or understanding the relationships between race and gender.

And on the question of racialization, especially the Irish becoming white and what-not, I respond to that both as the grandchild of immigrants, and also a scholar of immigration. My mother was a second-generation Greek immigrant to the United States and her skin was darker than many so-called "black" people. So, this idea that the physicality can somehow be disconnected from some of the other categories, to me is just completely implausible. Siba might be the only one to know that my own child is not white. She was only four or five when she came home from kindergarten and asked "well what am I? I'm not white, and I'm not black." This is the dichotomous nature of race in the United States.

But I do think that ambiguous-or what I call liminal—categories are useful, precisely in that they push people to rethink that simplistic dichotomy. The kind of transformation of Irish into white people is actually really helpful to think about. All countries around the world, where there were immigrants from the Middle East and North Africa, had often very contentious legal as well as political battles as to whether these peoples were white or not. These are really important conversations to have. And if we just say, "well, it's about physicality, but you know, racialization is taking us in an unhelpful direction" then we might miss out on a lot of really important dynamics.

\section{Shirin M. Rai}

I think this is such an important question that Randolph has raised. I would also underline what Audie has just said. I've got three little vignettes to string together. Firstly, my husband is Irish-white Church of Ireland Irish family from Cork (the Republic) that migrated to Belfast (Northern Ireland) — and the first argument I ever had with him was about whether race applies to the Irish in the UK or not. Secondly, it's a similar issue to your child, Audie. My son's name is Arjun, which is an Indian name, and he looks more Indian than my younger son. He had a problem with the fact that I called him Arjun. His middle name is Adair, which is my husband's father's name. And so, I had to say to him that if you want to change your name you 
can do that. This happened about that same time as your child started asking questions, Audie: he had just started primary school.

And the next vignette is really meant to underscore the intersectionality of gender and race-how culture, masculinities and nationalities intersect. I came to the UK on a scholarship, with twelve other "scientists". Out of the twelve, there were three or four women; only two of us were social scientists from New Delhi and the rest were hardcore science people from small towns in in India. On the plane from New Delhi to London I heard for the first time Hindu narratives about Muslims. I'd never come across that before. At university, these young men saw us as a group of Indians at Cambridge sharing a cultural heritage. They would try and police my behavior to conform to their understanding of what it means to be Indian. You would be disciplined if you were seen with a white guy, or having a bottle of wine in your hand. Cultural authenticity plays out through gender troubles.

One more element to all this. Intersectionality is involved with border crossings, which always implicates the state. My understanding of this arose when I visited Luna House [the headquarters of UK Visas and Immigration]. At that time, I had an Indian passport. And I was so struck at the way in which we (my husband and I) were treated by state officials in comparison to another couple. The woman standing in the next booth to me was white; from her accent it was clear that she was absolutely working-class. She was with a black man, whom I learned later on was from Ethiopia. They were married and they wanted a visa. I was so distracted by the hostility with which the official was talking to this woman as opposed to the politeness of the official who was talking to me- "oh, you went to Cambridge", "oh, that's great" etc. This incident happened over thirty years ago, and I've never forgotten that. The state polices borders-national, class and racial.

So, I take your point Randolph: you can't just say that everything is equal. And at the same time, these intersections are really important to unpack.

\section{Sheila Nair}

Randolph, I think the point you made about intersectionality was a very interesting one. I agree with Audie and Shirin on this: you can't really navigate spaces in a neutral way, in a gender-neutral way, regardless of whether you challenge the binary, or where you fall on the spectrum and so forth (see Nair 2014). We might want to clarify what we all mean when we say we do intersectional analysis. But leaving that aside, I just really appreciate hearing all of the personal stories, which I think is so evocative of what we're trying to get at in this forum.

But we need to also think about how we are situated in the academy, which is itself a racialized space. I am reminded of how Chimamanda Adichie, in her novel Americanah, comes to a recognition of her blackness in America in a way she did not experience it while in Nigeria. (Well, at least the central character, Ifemelu, does and I'm assuming that this is what Adichie herself experienced.) And I was thinking about a parallel in terms of the study of race and IR. Despite all of the interventions, despite how far we have come over the decades, how do we describe this racialized space of IR as scholars of race? Put another way, how can (or should?) we 
address racial difference and its experience in the academy? In some ways, feminist theory - at least, some types of feminist theory-have become mainstreamed. But race remains relatively more marginal in the debates. I'm teaching two IR classes right now and have used [Ann] Tickner's "What Is Your Research Program?" where she challenges mainstream IR on gender neutrality. We might ask too whether IR, as a discipline, avoids acknowledging its race neutrality.

But putting those two-race and gender-together I think is really important. And I don't think enough of that is being done in the discipline. That's my concern in bringing up the question of intersectionality. Kimberlé Crenshaw has had a tremendous impact on the way some of us think about questions of intersectionality. Which is not to say that intersectionality doesn't have to be interrogated as wellwhat we mean by that and how we do it. I've seen very few works in IR that do this very well. In other words, it is not like everything is equally significant in any given exploration; nevertheless, the challenge is how to address that intersectionality in a meaningful way in the kinds of questions we ask.

\section{Roxanne Doty}

Randolph brought up the physical body. And I have to say, as somebody who has a physical body, but not being a person of color, I have always been aware of how easily my physical body moves, and with relative ease and relative safety. My awareness of this grew the more interested I became in borders.

I remember going to some conference in Copenhagen. I brought my daughter with me-she was seven or eight—and we had just finished a fourteen-hour plane journey. There's a huge, long line for checking people's passports, and the guard sees us and calls "come on up here!". And I'm like "whew, thank god!" So, we show him our passport and he declares "we love American tourists!" Of course, I took advantage of that. But I did have a long talk with my daughter afterwards about why that happened to us. Almost all the rest of the line were people of color-from Asia and Africa, dressed in traditional clothes. It was very obvious, and I was almost embarrassed. I like to think that if I had been alone, I would have just waited in line. But I used my daughter as an excuse.

\section{The contemporary field}

\section{Roxanne Doty}

Recently, watching what has been happening since George Floyd was murdered, I have been thinking about borders and race. I watched what has been happening in Portland, and I am thinking: "this is the border patrol that's on the street of Portland trying to control Black Lives Matter and saying that they are terrorists." So, where are borders? I think race has always been sort of a borderland issue and I think there are huge connections conceptually and politically in terms of how we react to borders and race in our internal cities. Everybody has been appalled by what happened 
in Portland and some other cities, but if you have paid attention to Homeland Security and ICE and the borderland areas in the past god-knows-how-many-years, what happened in Portland would be zero surprise to you (see Doty 2009). So, I thought that maybe I would do one last project along these lines as my final academic gig.

My sister lives in Minneapolis. Her son is bi-racial. He could be in the wrong place at the wrong time. It just becomes personal and very disturbing. I feel powerless, and honestly, as an Anglo-white woman, I think it's time for white people to shut up and listen. To listen to what African American leaderships are saying about Black lives matter. I want to try and say something about all this without trying to dominate the conversation.

\section{Shirin M. Rai}

In my university today, there are about twelve black and BAME [black, Asian and minority ethnic] women professors. But actually, there are quite a few non-white professors at Warwick, the majority of whom are international scholars; people like myself, Mustapha, and Krishna, who came to do a $\mathrm{PhD}$ and settled in for whatever reasons and didn't go back. And it always bothers me, because as I've been at Warwick for 30 years now: my students have become more diverse in the color of their skins and less diverse in terms of the depth of their pockets. So, class and race: when you don't get the two together, it really bothers me.

And that filters into some of the things that I am now working on: gender and work, especially, racialized care work, which is presently under real scrutiny. Even mainstream newspapers are writing about this issue in terms of Covid-19. Care work is now being disproportionately placed on those communities that are most vulnerable to COVID, namely, BAME communities.

\section{Errol Henderson}

I'm tired of these people who have "discovered" race. I wrote my dissertation on Afrocentrism and World Politics, which ended up becoming my first book (Henderson 1995). Originally, I was going to conduct a quantitative analysis of propositions from Afrocentric theory, but when I looked I just kept coming across vulgar Afrocentrism. Harold Cruise [the founding Director of the Black Studies Center at University of Michigan] would challenge me during my graduate studies: "What does an Afrocentric state look like? How would it operate in practice?" He was a materialist, he didn't like all the romantic stuff. So, mine was a critical empirical Afrocentrism. I had to go back to Cheikh Anta Diop, St Clair Drake, Anna Julia Cooper, WEB Du Bois, Walter Rodney. And in the book published out of my dissertation, just look among those whose work I cite: Imari Obadele, former political prisoner from the Republic of New Africa, and Chokwe Lumumba. I wanted to show that this too is our scholarship. That's not even to mention mentors like Professor Ron Walters [see above]. But IR scholarship hardly deals with the Afrocentric scholarship of the 1980s and 1990s. Ron Walters called this "footnote apartheid". I call it "bibliocide". 
Most professors in the US have never been activists, and activists are rarely professors. When people write as if we-activists/professors-don't exist, then I have a problem. I didn't attend my graduation from Michigan. That day I was at the gang summit in Kansas City. We brought together over 200 sets (i.e. gangs) from 22 different cities to organize a national peace treaty. So, when it comes to white supremacism, the reason I privilege so much the empirical work is that I want a theory that allows us to develop strategy to actually change the concrete reality that folks exist in (see for example Henderson and Leng 1999); as an activist I don't care about changing folks' mind but rather their behavior, specifically, their white racist behavior and their institutions that perpetuate it/them.

There's a recent cottage industry of scholars talking about race in IR, but are they talking about white supremacism? I don't do "race"-I do white supremacism. And I'm not talking about Pan-Africanism because I'm black. But in a white supremacist system, a Pan-Africanist transformation will transform the whole system because black is the lowest of the low. That's what I want to challenge; that's my project. And I don't believe that oppression anywhere is oppression everywhere. I don't do my politics by bromide or aphorism. Remember the story about one person from the tribe of Levi, one from the tribe of Judah, and a Samaritan. And one "good Samaritan" could teach the whole world a lesson. Now, why can't 40 million AfricanAmericans teach a universal lesson? I'm not trying to prove anything more than I can demonstrate. I'm taking up the obligation that I was taught by black folks who made a way for me; and that which they left to me and others.

\section{Audie Klotz}

Some people find my work a little too tame because I don't gravitate to some of the more post-structuralist/critical theory perspectives. I find myself in this limbo land, where, for instance, a lot of people in this conversation don't really engage in my work- no offense taken! At the same time, the power structure also doesn't systematically engage with my work. My scholarship was picked up primarily by people who work on human rights and that eviscerated its critical edge. People often read the synthesized version of my work while the original version had much more of a southern African edge to it with a much more bottom-up argument (see for example Klotz 1993). I was also pegged as someone who provides case studies and so I am oftentimes shoved into a literature review as an interesting case of apartheid. I am not, therefore, an IR theorist. This is part of the problem of getting race to be taken seriously: you get shoved into the case studies thing.

I spent a lot of my career, over the last 20 years certainly, working on migration. That's a parallel that I've noticed before between me and Roxanne [Doty]. We both started out in one way and we both segue to being concerned about migration at the same time that we've been thinking about race. We do it from different theoretical lenses which is fine. The point is that people who work on migration talk about race all the time. For me, it's like hanging out with the Africanists. It's the part of the water that you swim in. If you are a migration scholar, that's just taken as a given. 
So, you don't have to spend a lot of time telling people to talk about race because it's already there.

But I want to finish by talking about institutional structures of power. There continues to be the need for a lot of people to have sponsors rather than mentors, and they tend to be white men. In fact, white men are still, most of the time, the gatekeepers and the controllers of access to the academy and those highly visible avenues through which work gets noticed and debated. Over the years I have watched people who are supposedly advancing issues of Global South agency kowtowing to powerful white guys even when other scholars, including people in our present conversation, are actually doing the substantive work. By the way, I was lucky to have Locksley [Edmondson] mentoring me. So, as we older folks move up through the system, I think we have made some progress in opening doors in a variety of institutions. But we are nowhere near where we would really need to be to have these issues addressed from the center.

I will give one example. I was asked to contribute to a book that came out a few years ago on the state of the constructivist debate. We had a conference, as you often do with these things. In the conference itself, nobody was even willing to engage in that question. We talked quite a bit about gender because Ann Tickner happened to wander into the workshop. In my paper I combined conversations about gender and race, because constructivism is pretty bad on both of those. So, we had all these hidden conversations. When I saw the final edited volume, I realized the editors had not asked a single person to address the critique that I had raised in the workshop. Nothing in the volume addressed anything concerning what I called the race gap. One or two people mentioned issues of race because they have already been thinking about these things albeit not extensively. So, I figure that we still need those editors to push people to actually be accountable for some of these arguments. We are still getting shoved to the side. I have been able to put some of these issues on the table precisely because I am a white woman and some people didn't find that presence quite as threatening.

\section{Mustapha Kamal Pasha}

Race, for me, has become more interesting in the course of studying critical theology. I began to see the theological formation of race, and how religion has been critical in the formation of racial categories (Pasha 2017). There are multiple pathways; I cannot draw a straight line or a linear pathway.

But to finish with, I want to say that we have a very rich theoretical and conceptual apparatus of visibility and invisibility. We cannot treat race as an exogenous category, bringing it in and bringing it out, zooming in and zooming out conveniently. Instead, we need to use that apparatus to treat race as an integral part of understanding critical theory, of understanding our enterprise of IR. We really need to work as a collective, as a team, to come at this issue and make it more legible and visible (see Pasha 2016).

Many of us were working on this issue in the early 1990s. Of course, Robert [Vitalis] has demonstrated race's congenital presence to IR: his book has completely demolished 
the mainstream narrative. Rob [Walker], of course, has been supporting these efforts for a long time, and his role as an editor of the journal Alternatives cannot be minimized in any sense. He has been pivotal in his own way, supporting these efforts and collective projects. So, I am thankful for all these people coming together.

\section{Sankaran Krishna}

So, have things changed? The short answer to that is yes. And I want to make a distinction between the discipline and reality that it studies. As a discipline, absolutely. A very crude indicator: just the level of social comfort that I, Shampa, Mustapha, or Randolph etc. feel at the ISA today is incomparable with our first trips there 20 years ago. And there now exists journals where I could conceive of sending a piece like my first writings and having a shot at being published there. The editorial boards are different: they are younger and more diverse in terms of race. There's also a corpus of publications that you can now draw upon and reference. All of those things build a kind of momentum. But I am always skeptical about what that means as far as reality is concerned. We know that racial hierarchies, patriarchy etc. are perhaps embedded deeper than before, because let's not forget we have now had four full decades of the neoliberal project working itself out.

Aside from that, what has really struck me between the eyes over the last 10 years is the extraordinary degree to which we Indians and South Asians are racist. Everything that I had been observing about IR in terms of strategies of abstraction and amnesia when it came to race, well, the upper caste middle-class India was doing vis-à-vis our own social formation. So rather than decolonize IR, which is, I think, a thankless venture-forms of representation are always going to follow material distributions of power and so there is a contradiction built into that business of decolonizing IR without decolonizing the world-I am more interested now in understanding how a figure like Gandhi helped Indian middle class secure itself as decolonial, as progressive etc. (Krishna 2015).

How did our narratives of the Indian national movement-Shirin, you and I grew up reading in those new textbooks-how did they make the middle class in India so oblivious to its own racism? I think we are seeing the wages of that occlusion today, as a Hindu fundamentalist party not only has India by the jugular, but looks like it has transformed the Indian experiment in ways that there may be no coming back from. So for me, the study of race and the study of the absence of race in IR has now come full circle home. I am less interested in decolonizing the North American discipline and more invested in thinking about the enormous similarity between how white IR has produced and reproduced itself and how upper caste Brahmin Hindu India has produced and reproduced itself... with probably very fatal consequences in both places.

\section{Siba N. Grovogui}

I want to finish by recalling the day I decided that I was going to study IR. Some idiotic French man comes to class and tells me: "Kaiser Canal belongs to the Germans", "Panama Canal belongs to Americans because Americans dug it", and that 
the Suez Canal was international until Nasser changed it. I raised my hand and said "what makes Kaiser Canal German?" and he said "well, because it's in Germany and the Germans dug it"; and I said: "Is Suez French territory?". The idea that Nasser was mistaken because he changed the international order: seriously? The conceit that Nasser could not change the international order, but the French could? I still have the copy of my class notes! The idea that we can't see in other people who we are, and we can't imagine other people doing what we do, desire what we desire, and act upon them in the way that we do: why not? That's how I came into race and IR.

And then in America race became about identity, and I have been struggling with that. I don't want someone to see me as black. I want them to let me tell them I am black and what that means to me and to them. Because I am black, but it is not for you to tell me that; I know that, and I tell you what that means, because that's what tells me about my humanity and yours (Grovogui 2001). But this idea that everywhere I go it is about identity-I fill out a form which asks if I am black or whatever descent-even today it bothers me profoundly. In Africana studies we are trying to talk about the post-Freud moment, and we forget that people who fought for civil rights in this country actually were not the identity that we are today.

When Martin Luther King went to India, he was invited by the premier of Kerala, who was a communist, to a school and the school teacher introduced him as a Dalit. That is a fact. If we forget that then we lose something about what race has done to us and how we can actually use it productively, in many ways. Yes: MLK went to India, he went to Kerala, and he was called a Dalit. So, for me, talking about race is always to talk about humanism and humanity. One more story. When Joe Slovo [a South African politician from a Jewish-Lithuanian family, a leader of the South African Communist Party, as well as a commander in the ANC's military arm during apartheid] died, a 14-year-old black South African nearly punched another black 14-year-old in his face when the latter said "you are going to the funeral of that white man?" The other 14-year-old said, "that is not a white man, that is Joe Slovo". Today you could not say that in South Africa.

\section{Shampa Biswas}

One of the worlds I inhabit right now is with a group of activists who draw attention to the dangers of radioactive contamination around nuclear sites globally. It's a real motley crew of downwinders, public health experts, scholars, artists, etc. We know that radiation itself is invisible, right? It has no sound or color or smellit's inaudible, it's invisible, it's impervious to the senses. But it's all around us- the background condition of our lives. In fact, we have decided as a society that there is a certain acceptable level of background radiation, an elevated level since the bombings of Hiroshima and Nagasaki as well as atomic tests around the world. We take it for granted and that's ok.

I feel like that's also the case for racism in IR. It sometimes feels like even most of the antiracist work in IR accepts a certain level of racism as given. People in my community of activists working on radioactive exposure say: "even if you can't see radiation, once you see it, you cannot unsee it. You always see it as 
present around you and inside of you-it's always there". And I feel like that's the case with race: once you see it, you can't unsee it. There's a lot of psychic labor that goes into unseeing it and I think that's true of a lot of our colleagues in the discipline. They see race, they have seen race, they have been led to see race, but they work at not seeing race. It feels to me that some of the shock that came after the George Floyd murder-with all these liberal woke people wanting to have all kinds of forums on race-I feel like it comes out of a sense of release that people feel from having to acknowledge something that they have seen all along but have been working not to see.

But in my world of nuclear activists who see radiation everywhere, they don't always see race everywhere, and of course, the nuclear world is thoroughly racialized (Biswas 2014). From Uranium mining to nuclear testing sites to the treatment of nuclear workers, including at Hanford near where I live now, it's a thoroughly racialized world. I love those activists, I think they are wonderful people. But learning to see race everywhere and all the time in the same way that you see radiation everywhere takes practice.

Once I saw race-race as lived condition, race as a structuring principle of the world - there was for me no way to unsee it, even though, like Shirin, I don't identify as a scholar of race. When people ask me what my expertise is, I will usually say nuclear non-proliferation and disarmament, global nationalism as a form of racism, global developmentalism as a form of racism, I'd even say postcolonial theory, but I rarely identify myself as a scholar of race. And I think there's a question here for us as a community to think about: what authorizes us as scholars of race? What makes us experts in race?

Even if I don't identify as a scholar of race, race informs everything I write and how I write, how I teach, how I parent, the ways I inhabit my institution, my workplace. And I also want to say in that context, that it is not just depressing; all the anti-racist work and pedagogy that I do is joyful and inspiring. And I think we need to hold onto that, too. And it's one of the reasons why being in this community of scholars feels joyful. It's important to remember how the ISA went from being a very unjoyful to a joyful place once I found a community of scholars who work on race, who engage with race as a problematic.

I have one final comment, which several people have already picked up on. Learning to see race does not automatically make it easy to learn how to navigate different worlds. I find all of us have lived these worlds in somewhat schizophrenic ways, depending on where we find ourselves. For me, this came to a head in 1998 when India became a nuclear power, which I found to be an absolutely indefensible decision. And yet I found myself defending it in some circles in the US because of the racist backlash, or the ways that people in the US represented that decision. So, for me, seeing race and learning to live with a racialized consciousness is to learn to speak in multiple registers simultaneously (see Biswas 2001). For me, that also means trying to make sense of living as a settler colonialist where I live right now. Krishna talked about the racism in Indian communities, both in India as well as in the Indian diaspora, and that's always a negotiation. There is no easy resolution there. 


\section{Sheila Nair}

It seems to me that bringing in intersectionality could be a really critical intervention in addressing not only race but intersecting oppressions in our work and in our everyday lives. My edited volume with Geeta Chowdhry back in the early 2000s, Power, Postcolonialism and International Relations (Chowdhry and Nair 2002), which many of you here contributed to, grew out of our conversations about what we felt was missing in this regard. These were conversations that we had over lunches and dinners, brown bags, colloquia, and ISA meetings. It was clear to me back then and now that many of us feel very similarly about these questions even if we come at them informed by our own experiences. Keeping some of these criticisms in mind, we still need to acknowledge the ways in which race, gender, and class, but clearly also sexuality, ableism, and caste (among other things) intersect, oppress and transform social relations and political discourse.

Like Shampa and others here, I don't consider myself a scholar of race per se. My work on Southeast Asia has been really formative though in terms of how I think about racial and ethnic constructs and their intersection with class and gender. I was struck by what Krishna said about moving away from studying race in North America towards studying caste in India. I think he raises some fascinating points about the futility of decolonizing white or racialized IR. I am not ready to give up on that, but I do agree that there might be other more productive and potentially less futile ways to engage questions of race in IR in our teaching and scholarship.

I have been recently working on a paper on two Southeast Asian writers: Pramoedya Ananta Toer (Indonesia) and Vu Trong Phung (Viet Nam) in the hope that I can show how these authors grappled with and navigated in their work the break with Eurocentrism and its postcolonial afterlives. For instance, I am very interested in Pramoedya's work on the Chinese in Indonesia. The ethnic and class stratified Dutch colonial society in which the Chinese were inserted in the "privileged" middle but were later seized upon as an opportunistic, immigrant economic elite with communist aspirations, had "fatal consequences" as well, to use Krishna's phrase. What this illustrates is of course how race and racialization (a juxtaposition of ethnic Chinese and native Indonesian identities, for example, by the colonial and postcolonial state) have different meanings and implications in the Indonesian context than it might in the US, but at the same time allows us to make connections that might otherwise not be made between the here and there.

Shifting course a bit, I wonder, as junior scholars anticipate where and how they can make their mark, whether there is any more openness and interest for critical studies on race in IR than when I first started in the field. Journals also play a gatekeeping role in terms of what gets counted as credible scholarship. While some of us are content to stay in our non-mainstream areas and to disidentify with IR, we might be contributing to a sort of disengagement that leaves us with little power to assist in creating a more expansive embrace of critical intersectional work in IR or serve as a resource for young scholars. It's very hard to get a critical paper on race published, for example, in International Organization. I'm not saying that's the only objective; and we should be happy publishing in other spaces. Besides, mainstream journals are themselves reproducing forms of racialized power and instituting relations in the 
academy that are policing and oppressive. But for junior scholars, as for us all, the challenge remains as to how to make race and its intersections become a much more focal and critical engagement in the discipline and not banished to IR's periphery.

\section{Neta Crawford}

Well, I want to approach race and racism in the current moment by thinking about militarization. I've been looking at the way that native people were treated in US warfare and that has helped me to provide a different explanation of American political development and its institutions. Basically, it's about how we got to be this continental imperial settler state. The idea that Europeans came to North America-an empty continent - and then just closed the frontier at some point is so enraging and erasing. No. Something else was going on. The US was constantly at war. And wars make states, right? So the story of American political development must be told, hand in hand, with how the continent was settled. Force is the American way of politics and all the way along we're waist deep in the blood. There is a thread of American diplomatic history that stresses the U.S. as an isolated and essentially peaceful country until it is dragged into the World Wars. But if we take the long view, from the colonial era forward, there was no period of isolation.

Focusing on the "Indian Wars" - that's what they were called, I'm not saying it's the appropriate nomenclature-is a way of telling the story of American foreign policy and domestic politics all at the same time. It exemplifies the persistent way in which the US fights by focusing on civilians: either destroying their food, or trying to coerce them directly by annihilation or encirclement or dispossession or through reservations. It's about controlling citizens, even when it's about trying to win hearts and minds. The US wars of the 21 st century have their roots in the American way of war of the 1600s, 1700s and 1800s. And that's where you get to racism.

In fact, this form of warfare originally comes from the Greeks and Romans. (So I might be telling a Eurocentric story here, but it's a different kind of Eurocentric story.) It's used by the British against the Irish [beginning in the late $1500 \mathrm{~s}$ with the wars to establish English "plantations"]. And that's a war definitely pursued in racialized terms. There's always an othering of the people you want to harm, and the rationale is that these people were supposedly savages. [Gaelic Irish peoples were compared to native Americans by English colonizers]. The starvation and the beheading, the sort of sheer terrorism of the Irish occupation by the English: the same people go and do that in North America! It's a way of war.

And so I think racism is an essential part of the story. But let me be clear, it's not the only thing going on. I'm trying to get at an ideology about the utility of force when applied to civilians. Think about World War Two. The starvation blockade of Germany was not about different races, but it certainly targeted civilians; so too strategic bombardment in both Germany and Italy. It's interesting to think about all this in terms of 2020.

I want to finish by going back to the native American peace confederacies. One of the things I've been saying for a while is not simply that another world is possible; in fact, we've always had another world. The world has been otherwise, and it could 
still be so. We can of course go into bloody detail about the physical, ideological and economic mechanisms of domination. But we also need to think about what native peoples were doing-what were their institutions? There's an agency there that doesn't have to be just framed in terms of what the dominant actor ends up being and doing. We have to talk about different forms of relating, for instance, different systems of justice.

\section{Anna M. Agathangelou}

In my recent work I have become interested in the way in which race is always thought of as a thing of the past and as something that is not sexually and gender informed and shaped (Agathangelou and Killian 2017). In a temporal sense, all empires and centers of global power tend to think of race as something of the paste.g. enslavement or colonization - and even going so far as to set it up against sexuality and gender, while as a counterpoint they conceive of themselves as authoring a new modern world. Thinking race through temporality is crucial. Time itself structures race and writes most global raciality projects.

But I also wanted to finish by responding to Bob [Vitalis]. You were talking about how we tell this story of race and IR: who were the first? Etc. But in this conversation, we've also talked about our own stories. Have they only been about race? We have talked about identity, colonial and enslaving structures that modernity depends upon and then abstracts away from. The point I am making is one that addresses Sheila's question about how we live, relate and work with junior scholars. I do not think they should do "what we do". We need to think about what conversations we can have with junior scholars and our students in terms of their own existential anxieties, concerns, questions.

This is also part of the problematic that we are trying to grapple with: there is always this idea of the "mentor" training the "apprentice". I am not entirely against that, but I think it nonetheless goes against a peripatetic and poetic way of understanding our present conditions. It goes against education and learning as an organic relation that is not independent of the society in which we exist, as I said in the beginning of our conversation. Are we, as academics and members of the world, willing to create the conditions and work with our junior faculty and students and others to cultivate an eco-system suitable for all peoples to grow up in the best possible and most thriving manner?

And there is another issue connected to this question of "training". Recalling what [Sankaran] Krishna said, I think we do feel that there is a bit more space in ISA nowadays, partially because lot more of us are there. But then I wonder whether there is a way for us to be exerting more pressure in the way we imagine, articulate and organize the field. Because there is hardly ever an accounting of the people that brought race to the table of IR. For me, race was always there: it was anti-colonial movements-people from the Second and Third World-who brought race to the table. And they were always bringing gender too; these were never separated, ever! If I am black man from Africa or a Cypriot woman from Cyprus I am already 
bringing those things to the table. And as I said previously, white supremacy, racial capitalism and patriarchy are not separated from each other. They are interlinked.

But the problem - as Krishna was saying - is that disciplinary forms of organizing, whether it be through journals or panels etc. are not conducive to asking such questions and taking account of them. Instead, it always has to begin and end with the academic field such that our material and political collective conditions are deemed not important to and in conversation with scholarship. So, the field becomes a prioritizing mechanism through which we write anything except our life conditions, our form and shape, and how we relate and speak to the field. This is another way to think about what the "next generation" means: how we engage with each other (senior, junior etc.) but also how the field is articulated and how we claim the field itself. Academic IR cannot dictate to us what we must prioritize. This field is us; the field is not a universal, a formal static entity; it is a materiality, a configuration, which includes mechanisms of violence and possibility that do facilitate expropriation and exploitation but also can create the intellectual tools that can rupture "this" world for a planetary otherwise.

\section{References}

Agathangelou, A. M., \& Killian, K. D. (2017). Time, temporality and violence in international relations: (De)Fatalizing the present, forging radical alternatives. London: Routledge.

Bhambra, G. K., Bouka, Y., Persaud, R. B., Rutazibwa, O. U., Thakur, V., Bell, D., et al. (2020)."Why is mainstream international relations blind to racism? Foreign Policy (blog). https://foreignpolicy. com/2020/07/03/why-is-mainstream-international-relations-ir-blind-to-racism-colonialism/.

BISA. (2020). Black lives matter-A BISA statement on recent events. BISA. June 2020. https://www. bisa.ac.uk/news/black-lives-matter-bisa-statement-recent-events.

Biswas, S. (2001). Nuclear Apartheid' as political position: Race as a postcolonial resource? Alternatives: Global, Local, Political, 26(4), 485-522.

Biswas, S. (2014). Nuclear desire power and the postcolonial nuclear order. Minneapolis: University of Minnesota Press.

Blain, K. N. (2020). Civil Rights International, September 9, 2020. https://www.foreignaffairs.com/artic les/united-states/2020-08-11/racism-civil-rights-international.

Chowdhry, G., \& Ling, L. M. H. (2018). Race(Ing) international relations: A critical overview of postcolonial feminism in international relations. Oxford Research Encyclopedia of International Studies. https://oxfordre.com/internationalstudies/view/10.1093/acrefore/9780190846626.001.0001/acref ore-9780190846626-e-413.

Chowdhry, G., \& Nair, S. (Eds.). (2002). Power, postcolonialism and international relations. London: Routledge.

Chowdhry, G., \& Rai, S. M. (2009). The geographies of exclusion and the politics of inclusion: Racebased exclusions in the teaching of international relations. International Studies Perspectives, 10(1), 84-91.

Crawford, N. C. (1994). A security regime among democracies: Cooperation among Iroquois Nations. International Organization, 48(3), 345-385.

Crawford, N. C. (2002). Argument and change in World Politics: Ethics, decolonization, and humanitarian intervention. Cambridge: Cambridge University Press.

Crawford, N. C., \& Klotz, A. (1999). How sanctions work: Lessons from South Africa. New York: St. Martin's Press.

Doty, R. L. (1993a). Foreign policy as social construction: A post-positivist analysis of U.S. Counterinsurgency Policy in the Philippines. International Studies Quarterly, 37(3), 297-320.

Doty, R. L. (1993b). The bounds of 'Race' in international relations. Millennium, 22(3), 443-461. 
Doty, R. L. (2009). The law into their own hands: Immigration and the politics of exceptionalism. Tucson: University of Arizona Press.

Edmondson, L. (1968). The internationalization of black power: Historical and contemporary perspectives. Mawazo 1(4).

Edmondson, L. (1969). The challenges of race: From entrenched white power to rising black power. International Journal, 24(4), 693-716.

Edmondson, L. (1973). Race, politics and the international system: Aspects of research and behavior. Kingston: Queen's University.

Grovogui, S. N. (1996). Sovereigns, Quasi Sovereigns, and Africans: Race and self-determination in international law. Minneapolis: University of Minnesota Press.

Grovogui, S. N. (2001). Come to Africa: A hermeneutics of race in international theory. Alternatives, 26(4), 425-448.

Grovogui, S. N. (2008). No more no less: What slaves thought about their humanity. In G. K. Bhambra \& R. Shilliam (Eds.), Silencing human rights: Critical engagements with a contested project. Basingstoke: Palgrave Macmillan.

Henderson, E. A. (1995). Afrocentrism and world politics: Towards a new paradigm. Westport, Conn: Praeger.

Henderson, E., \& Leng, R. J. (1999). Reducing intergang violence: Norms from the interstate system. Peace \& Change, 24(4), 476-504.

Henderson, E. A., \& Tucker, R. (2001). Clear and present strangers: The clash of civilizations and international conflict. International Studies Quarterly, 45(2), 317-338.

Howell, A., \& Richter-Montpetit, M. (2020). Is securitization theory racist? Civilizationism, methodological whiteness, and antiblack thought in the copenhagen school. Security Dialogue, 51(1), $3-22$.

ISA. (2020). ISA Statement Condemning Racism > International Studies Association. June 2020. https://www.isanet.org/News/ID/5802/ISA-Statement-Condemning-Racism.

King, M. C. (1985). Complexities of U.S.-Nigerian relations: Legacy, prospects. Transafrica Forum, $3(1), 39-60$.

Klotz, A. (1993). Race and Nationalism in Zimbabwean Foreign Policy. The Round Table, 82(327), $255-279$.

Klotz, A. (1995). Norms in international relations: The struggle against apartheid. Ithaca: Cornell University Press.

Krishna, S. (1993). The importance of being ironic: A postcolonial view on critical international relations theory. Alternatives: Global, Local, Political, 18(3), 385-417.

Krishna, S. (2001). Race, Amnesia, and the education of international relations. Alternatives, 26(4), $401-424$

Krishna, S. (2015). a postcolonial racial/spatial order: Gandhi, Ambedkar, and the construction of the international. In A. Anievas, N. Manchanda, \& R. Shilliam (Eds.), Race and racism in international relations: Confronting the global colour line (pp. 139-156). London: Routledge.

Mohdin, A., \& Swann, G. (2020). How George Floyd's death sparked a wave of UK Anti-Racism Protests. The Guardian, July 29, 2020, sec. UK news. https://www.theguardian.com/uk-news/2020/ jul/29/george-floyd-death-fuelled-anti-racism-protests-britain.

Murji, K., \& Solomos, J. (2016). Introduction to symposium on theories of race and ethnicity. Ethnic and Racial Studies, 39(3), 374-374.

Nair, S. (1999). Colonial "Others" and Nationalist Politics in Malaysia. Akademika, 54(1), 55-79.

Nair, S. (2014). Women of color faculty and the 'Burden' of diversity. International Feminist Journal of Politics, 16(3), 497-500.

Palmer, A. (1983). The politics of race and war: Black American Soldiers in the Caribbean Theater During the Second World War. Military Affairs; Lexington, 47(2), 59-62.

Pasha, M. K. (2016). The Bandung Within. In Q. N. Phạm \& R. Shilliam (Eds.), Meanings of Bandung: Postcolonial orders and decolonial visions (pp. 201-210). London: Rowman \& Littlefield International.

Pasha, M. K. (2017). Religion and the fabrication of race. Millennium, 45(3), 312-334.

Persaud, R. (1997). Frantz Fanon, race and world order. In S. Gill \& J. H. Mittelman (Eds.), Innovation and transformation in international studies (pp. 170-184). Cambridge: Cambridge University Press.

Persaud, R. B. (2001). Racial assumptions in global labor recruitment and supply. Alternatives, 26(4), 377-399. 
Persaud, R. B. (2015). Colonial violence: Race and gender on the sugar plantations of British Guiana. In A. Anievas, N. Manchanda, \& R. Shilliam (Eds.), Race and racism in international relations: Confronting the global colour line (pp. 117-138). London: Routledge.

Persaud, R. B., \& Walker, R. B. J. (2001). Apertura: Race in international relations. Alternatives, October.

Rai, S. (2002). Gender and the political economy of development: From nationalism to globalization. Cambridge: Polity Press.

Shilliam, R. (2020). When did racism become solely a domestic issue? Foreign Policy (blog). https://forei gnpolicy.com/2020/06/23/racism-ir-international-relations-domestic/.

Stanford, K. L. (1997). Beyond the boundaries: Reverend Jesse Jackson in international affairs. Albany: State Univ. of New York Press.

Vitalis, R. (2000). The graceful and generous Liberal Gesture: Making racism invisible in American International Relations. Millennium, 29(2), 331-356.

Vitalis, R. (2007). America's Kingdom: Mythmaking on the Saudi Oil Frontier. Stanford: Stanford University Press.

Vitalis, R. (2015). White World Order, Black Power Politics: The birth of American international relations. Ithaca: Cornell University Press.

Wæver, O., \& Buzan, B. (2020). Racism and responsibility-The critical limits of deepfake methodology in security studies: A reply to Howell and Richter-Montpetit. Security Dialogue, 51(4), 386-394.

Walker, R. B. J. (1984). Culture, ideology, and world order. Boulder: Westview Press.

Zvobgo, K., \& Loken, M. (2020). Why race matters in international relations. Foreign Policy (blog). https ://foreignpolicy.com/2020/06/19/why-race-matters-international-relations-ir/.

Publisher's Note Springer Nature remains neutral with regard to jurisdictional claims in published maps and institutional affiliations. 